\title{
WILEY
}

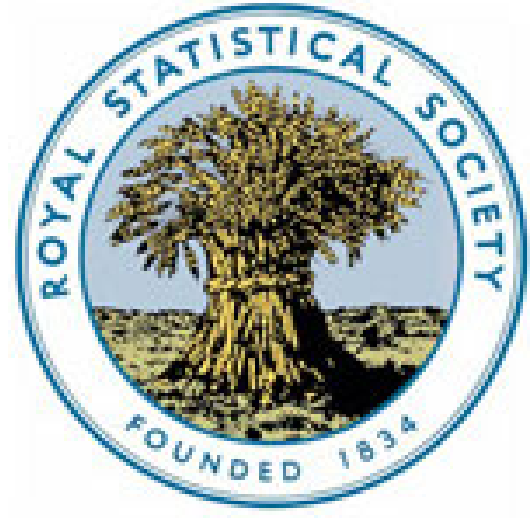

On Marriage-Rates and Marriage-Ages, with Special Reference to the Growth of Population Author(s): William Ogle

Source: Journal of the Royal Statistical Society, Vol. 53, No. 2 (Jun., 1890), pp. 253-289

Published by: Wiley for the Royal Statistical Society

Stable URL: http://www.jstor.org/stable/2979409

Accessed: 24/06/2014 21:13

Your use of the JSTOR archive indicates your acceptance of the Terms \& Conditions of Use, available at http://www.jstor.org/page/info/about/policies/terms.jsp

JSTOR is a not-for-profit service that helps scholars, researchers, and students discover, use, and build upon a wide range of content in a trusted digital archive. We use information technology and tools to increase productivity and facilitate new forms of scholarship. For more information about JSTOR, please contact support@ jstor.org.

Wiley and Royal Statistical Society are collaborating with JSTOR to digitize, preserve and extend access to Journal of the Royal Statistical Society. 


\section{On Marrtage-Rates and Marriage-Ages, with Special Reference to the Growth of Population.}

By Dr. William Ogle, M.A., F.R.C.P., \&.

[Read before the Royal Statistical Society, 18th March, 1890.

The President, Dr. T. Graham Balfour, F.R.S., in the Chair.]

THERE are men who toil because work is a pleasure to them, and there are others who toil becanse work is a duty; but the great majority of mankind are only stimulated to labour, that in amount or character is distasteful to them, by the hope that they may be able, in the first place, to maintain themselves, and secondly to marry and maintain a family in that degree of comfort which they have come to regard as necessary. If, therefore, the well-being of a State consists in the material well-being of the people, a country is then most flourishing when the largest proportion of its population is able to satisfy these two natural desires; and thus the fluctuations from year to year in the marriage-rate become a fair measure of the ebb and flow of material prosperity; the fluctuations, be it noted, from year to year, not the differences presented by the rate at longer intervals. For when such longer periods are taken, there is an interfering cause which may very possibly vitiate the comparison. You cannot, for instance, say that because the marriage-rate in England and Wales was 17.5 per 1,000 in 1865, and only $14^{\circ} 4$ in 1885 , the people were worse off at the latter than at the former date. For the standard of comfort may have changed, and indeed doubtlessly had changed, very considerably in the interval, and men, who in 1865 may have thought themselves justified in venturing on matrimony when they had a fair prospect of a certain amount of earnings, may at the latter date have come to consider such an income as utterly inadequate for the proper support of a family. But such changes in the general standard are only brought about gradually, and consequently the fluctuations in the rate from year to year are not liable to this cause of fallacious interpretation. In this paper, therefore, the rate for any year will be compared with that of the year next preceding; and when the rate is said to have risen or fallen, it will be meant that it was higher or lower than the immediately preceding rate, and not that it was higher or lower than the preceding average.

Having made these few preliminary remarks, let me now call 
your attention to the figures in Col. 2 of Table $\mathrm{A}$, or to the diagram which follows it (Diagram A), the table giving the marriage-rate, that is the proportion of persons married ${ }^{1}$ in the year to I,000 population, for each year since 1820; while the diagram shows the same facts graphically for the years since 1839, inclusively, that is for all the years since civil registration began, and rates could be more accurately determined :-

TABLE A.

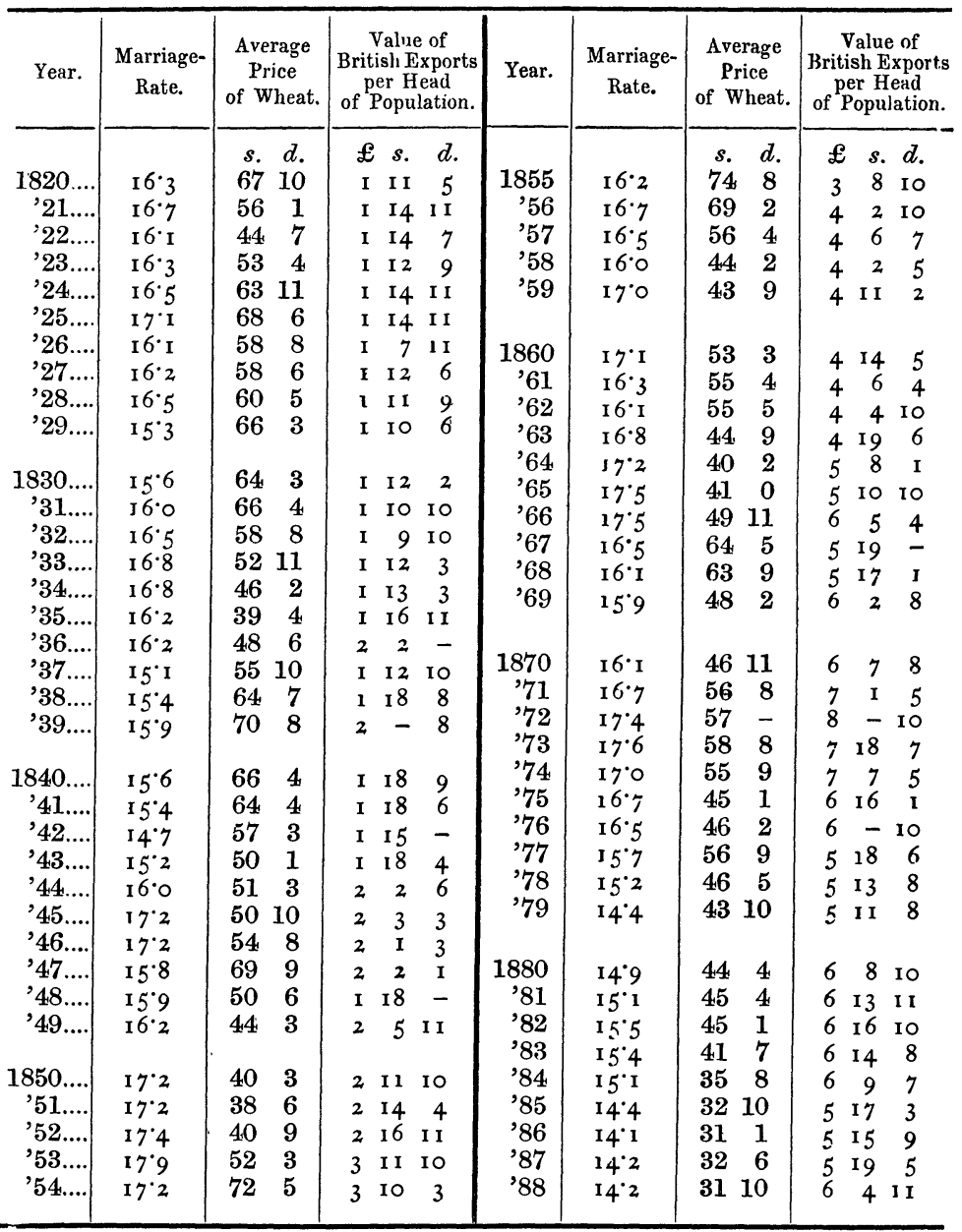

1 The marriage-rate may be expressed in two ways, either by giving the proportion of marriages or of persons married to 1,000 living. The rate by the latter method is of course double the rate by the other; and is the rate used in the official reports for England and Wales, and in this paper. 


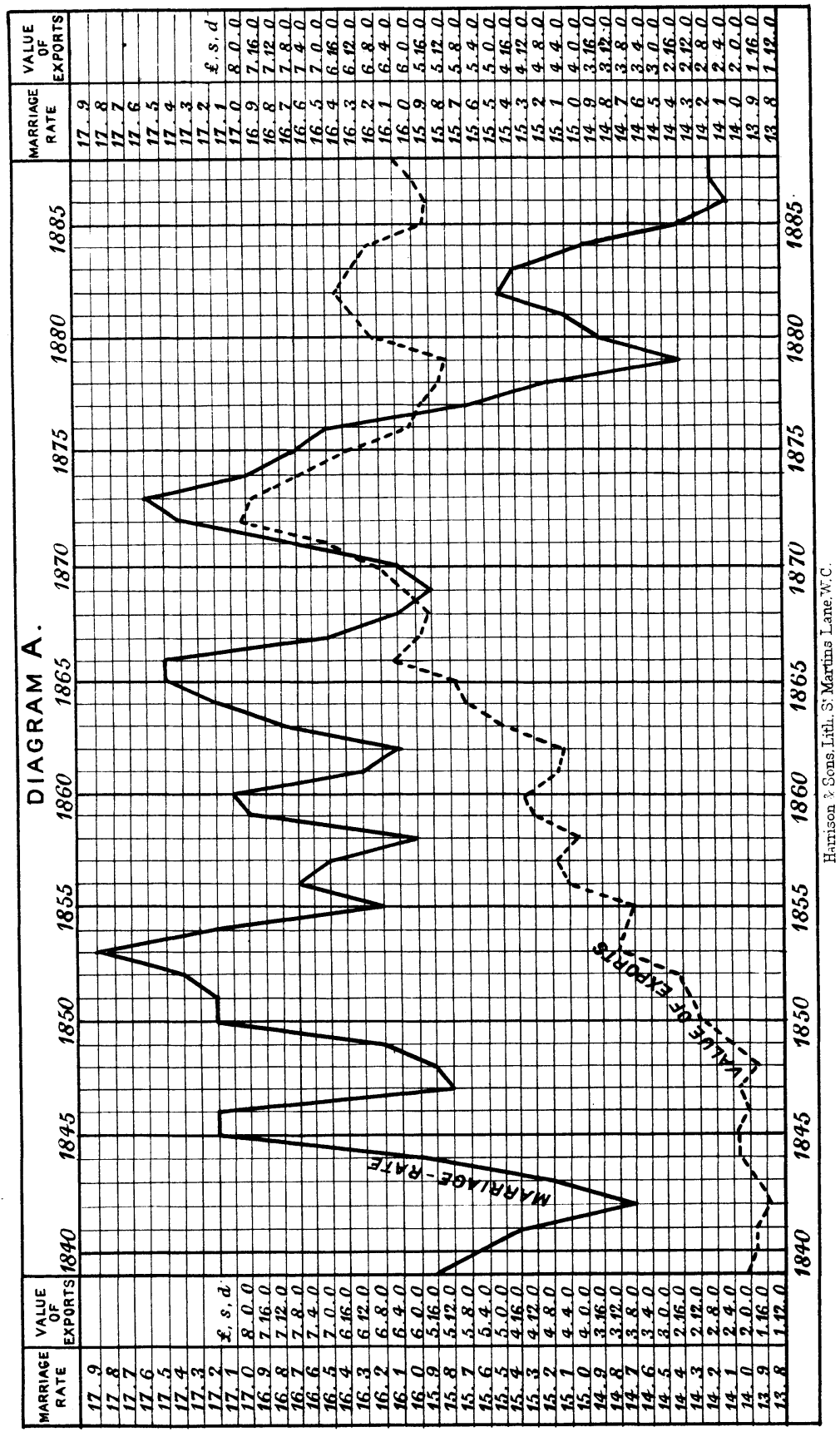


The figures and the diagram show that the marriage-rate has fluctuated in a very irregular manner, the line of the curve presenting a number of successive waves, differing from each other very greatly, both in length and in altitude. To what causes have these fluctuations been due?

Let us first briefly consider the effect of such great national catastrophes as war, pestilence, and famine.

The effect of war, removing as it does a considerable number of men of marriageable ages from the country, and interfering largely, moreover, with the industries of those who are not actually engaged in the struggle, is, as might be anticipated, to bring down the marriage-rate; but the extent of this reduction will of course vary according to the proportions which the war assumes, and according as the seat of war is abroad or in the country itself. Luckily, our own country has never been the actual seat of war since civil registration began, nor have our wars abroad been waged on the gigantic scale of other nations in modern times. Moreover, our armies have been constituted mainly of men who even in times of peace are debarred by the rules of their service from matrimony. Consequently, the effects of our wars upon the marriage-rate have been comparatively insignificant, and to find good examples of such effects we must go to the records of other nations. These records show that war depresses the marriage-rate enormously, but that, as soon as the war is over, the rate not merely recovers its former level, but rises temporarily to a much higher point than it had reached before, the rebound being almost, if not quite, invariably so great as fully to make up for the temporary depression. This recovery is to be explained by the fact that the population after a war will, owing to the cessation of marriages during its continuance, contain a larger proportion of unmarried persons of marriageable ages than usual, and also to the fact that numerous intended marriages will have been simply postponed, and not actually broken off, by the war. A few examples may be given. In 1864 Denmark was at war with Prussia, and its marriage-rate fell from $15^{\circ}$ to $\mathrm{I}^{\cdot} 3$, the lowest point it has ever yet reached, but in the next year, the war being over, rose to $17^{\bullet} 8$, and was higher than it has ever been again. In 1866 Austria was at war with Prussia, and, while the Prussian rate fell from $18 \cdot 2$ to $15^{\circ} 6$, the Austrian rate fell from $15^{\circ} 5^{\text {to }}$ i $3^{\circ}$, but on the cessation of hostilities, rose in 1867 to $19^{\circ} 3$, a higher level than in any earlier year. In the great war of 1870-71, the Prussian rate fell from $17^{\circ} 9$ in 1863 to $14^{\circ} 9$ in 1870 , and $15^{\circ} 9$ in 1871 , but in the two years afier peace was made rose to 20.6 and 20.2 , the two highest raties recorded in that country. Similar changes occurred simultaneously in France, the rate falling from 16.5 before the year to 12.1 and 14.4 , and then, war 
over, rising to 19.5 and $17^{\circ} 7$, the two highest French rates as yet recorded.

In our own country the effects of war upon the marriage-rate are happily, for reasons already given, not so conspicuous as in these foreign instances. Still, even in our own records, the effects can be plainly seen. The Crimean war began in 1854, and ended in 1856, and was followed in 1857 by the Indian Mutiny, which was finally suppressed in the beginning of 1859. Throughout this period of five years the marriage-rate remained depressed, but not to any great extent, nor was the recovery that followed in 1859 and 1860 on anything like the scale of the foreign examples which I have given. The rate in the year when the war commenced was $17^{\cdot 2}$, and fell during its continuance and that of the mutiny, to $16.2,16.7$, 16.5, and $160^{\circ}$; and then, the troubles over, rose to $17^{\circ} \circ$ and $17^{\circ} \mathrm{I}$.

If the effects of war are but little reflected in our marriagerates, still less visible are those of pestilence or famine. Such epidemics as appear amongst us from time to time, though terrible enough to those immediately concerned, yet as a matter of fact involve but a small proportion of the population, and neither in the cholera years, nor in the small-pox years is any falling off to be seen in the marriage-rate; and as to famine, we have had luckily as yet no experience in this country.

But though we are free from famine, we have considerable fluctuations from year to year in the abundance of food; and it is by these fluctuations in abundance, as measured by the changes in the price of wheat, that economical writers have been in the habit of explaining the fluctuations in the marriages. As the bulk of the population consists of the artisan and labouring classes, it is of course on the number of their marriages that the rate practically depends, and it would seem highly probable a priori that the price of food should be the main element in the comparative well-being of these classes. "According to all experience," says" J. Stuart Mill, "a great increase invariably takes place in the number " of marriages in seasons of cheap food and full employment;" and similarly Mr. Fawcett writes in his "Manual of Political "Economy," "There is no surer test of the prosperity of the "labouring class than the low price of bread, and there are few "statistical facts better substantiated than that the marriages " among the labouring class increase with the fall in the price of " bread." Unfortunately neither these writers, nor those other authorities in political economy who have made similar statements, give, so far as I have been able to ascertain, the actual figures on which their statements are based; so that it remains doubtful whether they have themselves personally examined into the facts,

$$
2 \text { “Political Economy;" II, xi, sec. } 2 . \quad 3 \text { Sec. 3, 6, p. } 78 .
$$


or whether they have merely adopted, without personal investigation, an article of general belief. But this can at any rate scarcely have been the case with that distinguished statistician, my official predecessor, Dr. Farr. Writing in the eighth annual report of the registrargeneral, Dr. Farr says : "Years of plenty are years of prosperity for "the people, and the marriages increase, with few exceptions, when " provisions are cheap." Of course, Dr. Farr, did not suppose that the sole cause which acted upon the marriage-rate was the abundance or the dearth of food. He fully recognised that there were other causes in operation, such as high or low wages, and the states of war or peace, and that these several causes admit of various combinations, that they sometimes neutralise each other, and that the marriage-rates express the combined result of them all. Still the words I have quoted, that " the marriages increase with few " exceptions when provisions are cheap," show, I think, conclusively that at the time when he wrote them he regarded the price of food as the main determining cause, which only in exceptional cases was counteracted by other influences. Dr. Farr cannot possibly have based this opinion upon the experience of the seven years that had intervened between the first establishment of civil registration and the time when he wrote the eighth annual report; for not only were those few years quite insufficient as a basis, but as a matter of fact their evidence, so far as it went, was against his conclusion; for out of those seven years there were no less than five in which the marriage-rate rose and fell concomitantly with a rise or fall in the price of wheat, and only two in which the supposed inverse relation existed.

Neither can Dr. Farr have based his conclusion apon the evidence of the marriage-rates as calculated from the data collected by Mr. Rickman, for the years before civil registration began; for, as may be seen in the figures in Table A, their evidence is also against him. Going back as far as 1820 , there were many more years in which the marriage-rate varied directly with the price of wheat, than there were years in which the two varied inversely. But in this Society, at any rate, we may feel pretty sure that Dr. Farr was not writing without facts to support him, and seeing how distinctly he states his conclusion, and seeing, moreover, that this conclusion tallies with that expressed by such economical authorities as Mill and Fawcett, we are, I think, justified in supposing that the data on which the opinion was based were derived from foreign sources, and in this supposition I am confirmed by finding that that indefatigable statistician, Signor Bodio, writing in $1876,{ }^{4}$ after stating that in certain foreign countries

4 “Del Movimento della Popolazione in Italia e in altri stati d'Europa," 1876, pp. 136 and 137. 
there was an inverse relation between marriage-rates and the price of food, goes on to say that he had been unable to detect any similar condition of things in the English records.

Most assuredly no such relation exists. Indeed the relation between the two is the very opposite. The marriage-rate varies not inversely but directly with the price of wheat. In recent years, that is to say in the last twenty years or thereabouts, this direct relation has been almost invariable, and though, in the years before that the direct relation was not so constant, yet even then there were many more years in which the rate and the price rose and fell together, than there were years in which the two moved in different directions. On this direct relation, however, I will not now insist; I shall have to return to it again. For the present it will be enough to say that while in some foreign countries, and very possibly in our own country in far removed times, marriages increase when food is cheap, and decrease when it is dear, no such phenomenon is presented in our records, at any rate so far back as the figures go in Table $A$, that is as far back as 1820. How is this difference between different countries to be explained? It appears to me to be only explicable on the supposition that there is or has been a wide difference in the general standard of comfort of the labouring classes in the different countries. When the standard of living is extremely low among the working classes, the question of marrying or not marrying is decided simply by the possibility of getting sufficient food, and consequently the price of food is then the main factor in determining the marriage-rate; but, when the standard of living has been considerably raised, mere sufficiency of food is no longer held to be an adequate justification of marriage, and consequently the price of wheat ceases to be the one determining factor, and becomes quite subordinate to the amount of wages. This however only explains why marriages do not increase in this country when food is cheap; it does not explain why they increase when food, or rather when wheat, is dear. But to this I shall revert presently.

If then the changes in the cost of food will not explain the fluctuations in the marriage-rate, what better explanation can we find? Or what is the best standard we can obtain by which to gauge those fluctuations in the well-being of the working classes which influence them in the matter of marriage? Of late years it has been customary in the annual reports of the registrargeneral, to put side by side with the successive marriage-rates not only the price of wheat, but several additional series of figures representing the changes in sundry accepted measures of national prosperity, such as the value of imports and of exports, and the amount of money cleared at the bankers' clearing house. 


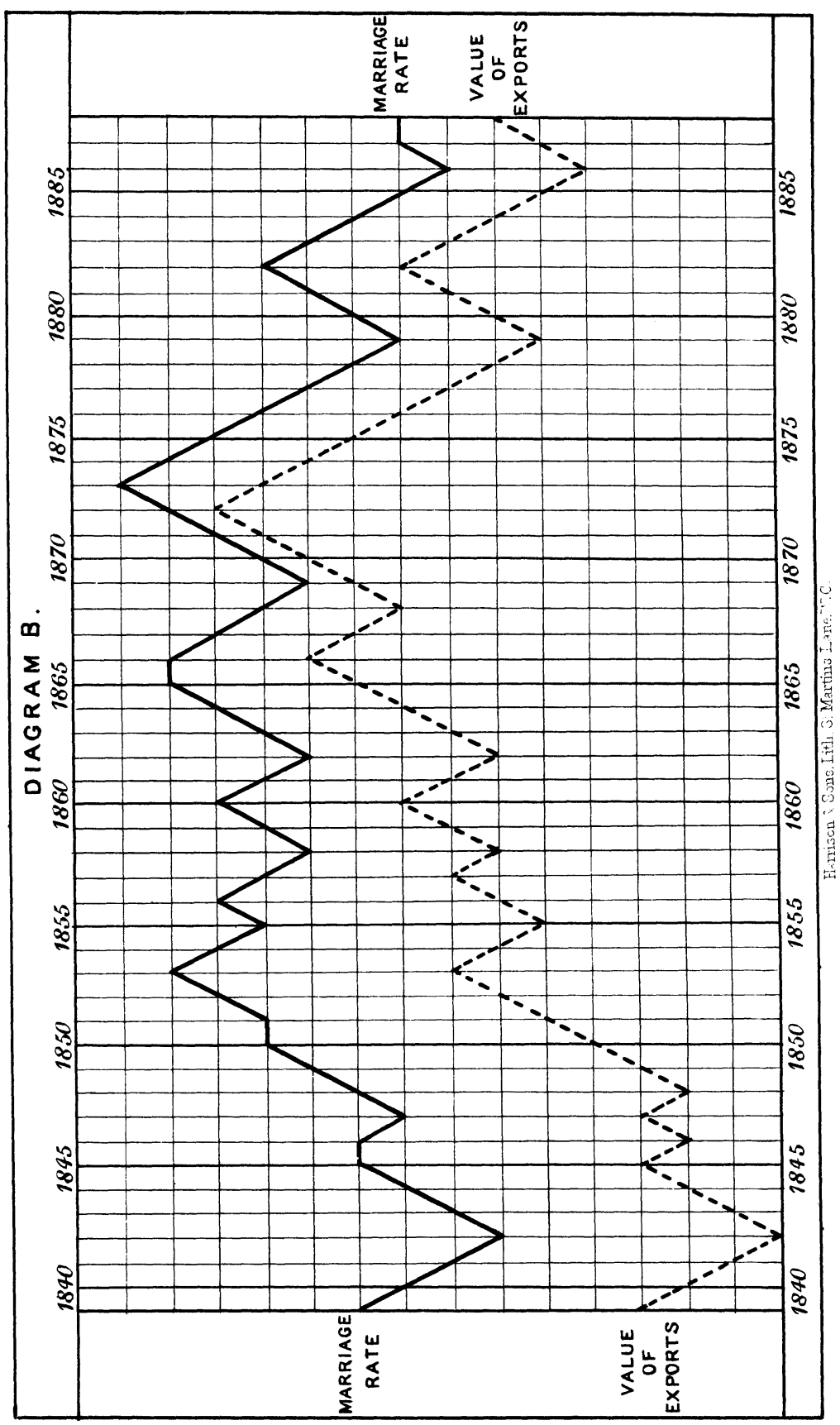


To these might be added other tests, such as the amount of pauperism, and the prices of other commodities than wheat; but the series in which the changes have been found to synchronise most closely with the changes in the marriage-rate is that which gives the value of British exports per head of the population; and I would therefore again call your attention to Table A; there you will find these values given side by side with the marriage-rate, for each year since 1820; or perhaps, as it is difficult to compare rapidly two series of figures, it will be better to refer to Diagram $A$, in which the changes in the marriage-rate and in the export values since 1838, when civil registration began, and the rates became more trustworthy, are graphically represented; the curve for the marriage-rate being the upper line, while the lower line is the curve of export values.

At first sight the two curves seem utterly unlike each other, especially in their earlier portions; the lower line showing, with many comparatively small irregularities, a continuous rise up to 187:3, while the upper line shows no such general ascent, but a series of irregular waves. But, on further examination, it will be seen that under this. striking dissimilarity there are hidden many notable points of agreement. The waves in the one line coincide invariably with waves in the other, the highest and lowest point in each wave coming moreover almost always in precisely the same years in the twro. The years 1846, 1853, 1856, 1861, 1867, 1873, and 1883 , each form an apex of a wave, or wavelet, in each line; while 1843, 1848-49,1856,1858, 1863, 1869, 1879, and 1887, are in each curve years when a wave is at its lowest. In short, the fluctuations in the two curves coincide almost exactly in position, though they differ very widely in their relative sizes. This is most clearly seen if we altogether ignore the size of the fluctuations and restrict our attention to their directions, as is done in Diagram B, where the line simply shows the direction, up or down, in which the marriage-rate and the value of British exports per head of population have moved from year to year. The two curves are almost identical. The diagram shows the changes from 1839 to 1888 , fifty years altogether. In all these years there are only five, namely, 1847, 1848, 1857, 1869, and 1873, in which the marriagerate moved in a different direction from the export values; there are three years in which the rate remained unchanged, while the exports rose or fell; while in all the remaining years the two rose or fell together.

Even some of the five exceptions are simply due to the fact that occasionally the rise in the marriage-rate does not exactly synchronise with the rise in exports, but follows at a short interval, so that the rate goes up in the year after the rise of exports, not in 
the year of the rise itself. This is seen by looking at the years 1869 and 1873 in the diagram.

The marriage-rate then goes up and down synchronously with the value of exports. This can clearly only be because the changes in these values are an indirect indication of corresponding changes in the employment and the wages of the labouring classes; and it would be desirable to obtain, if possible, some more direct measure of these latter changes. Hunting about for such a measure, I lighted, in the labour statistics of the Board of Trade, upon the annual returns made by certain trade unions, in which were given for a series of years the number of members on the books at the end of each year, and also the average monthly number of such members who were in receipt of benefit as being out of employ :-

TABLE B.

\begin{tabular}{|c|c|c|c|c|}
\hline $\begin{array}{c}1 \\
\text { Year. }\end{array}$ & $\begin{array}{c}2 \\
\text { Members } \\
\text { of the Unions } \\
\text { at } \\
\text { end of Year. }\end{array}$ & $\begin{array}{c}3 \\
\text { Average } \\
\text { Monthly Numbers } \\
\text { of } \\
\text { Unemployed } \\
\text { Benefit. }\end{array}$ & 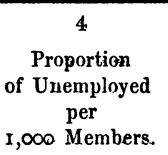 & $\begin{array}{c}5 \\
\text { Marriage-Rate } \\
\text { in } \\
\text { England and Wales. }\end{array}$ \\
\hline $\begin{array}{r}1867 \\
\text { '68 }\end{array}$ & $\begin{array}{l}55,721 \\
55,656 \\
55,398\end{array}$ & $\begin{array}{l}4,282 \\
4,963 \\
4,554\end{array}$ & $\begin{array}{l}77 \\
89 \\
82\end{array}$ & $\begin{array}{l}16 \cdot 5 \\
16 \cdot 1 \\
15 \cdot 9\end{array}$ \\
\hline 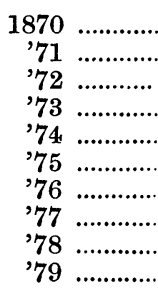 & $\begin{array}{l}57,494 \\
6 \mathrm{r}, 514 \\
67,29 \mathrm{I} \\
84,365 \\
88,366 \\
92,467 \\
95,787 \\
99,446 \\
98,582 \\
95,596\end{array}$ & $\begin{array}{r}2,627 \\
1,132 \\
718 \\
1,144 \\
1,658 \\
2,638 \\
4,113 \\
5,157 \\
7,257 \\
13,957\end{array}$ & $\begin{array}{r}46 \\
18 \\
11 \\
14 \\
19 \\
29 \\
43 \\
52 \\
74 \\
146\end{array}$ & $\begin{array}{l}16 \cdot 1 \\
16 \cdot 7 \\
17 \cdot 4 \\
17 \cdot 6 \\
17 \cdot 0 \\
16 \cdot 7 \\
16 \cdot 5 \\
15 \cdot 7 \\
15 \cdot 2 \\
14 \cdot 4\end{array}$ \\
\hline 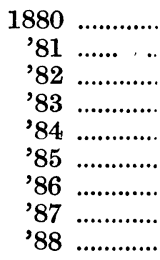 & $\begin{array}{r}96,919 \\
102,175 \\
112,482 \\
119,640 \\
122,941 \\
124,642 \\
122,444 \\
120,748 \\
124,238\end{array}$ & $\begin{array}{r}6,592 \\
3,925 \\
2,322 \\
2,894 \\
10,475 \\
12,765 \\
13,851 \\
10,518 \\
6,595\end{array}$ & $\begin{array}{r}68 \\
38 \\
20 \\
24 \\
85 \\
102 \\
113 \\
87 \\
53\end{array}$ & $\begin{array}{l}14 \cdot 9 \\
15 \cdot 1 \\
15 \cdot 5 \\
15 \cdot 4 \\
15 \cdot 0 \\
14 \cdot 4 \\
14 \cdot 1 \\
14 \cdot 2 \\
14 \cdot 2\end{array}$ \\
\hline
\end{tabular}

Combining the figures in the reports of these several unions into an aggregate, I obtained the results which are given in Col. 4 of Table B. In that column you have the proportion of unemployed per 1,000 members for each year from 1867, and side by side in the next column you have the marriage-rate for England 
and Wales. If you compare the two series of figures, you will see that there is a very close correspondence between their respective fluctuations, When the proportion of unemployed increases, the marriage-rate declines; when the proportion falls off, the marriagerate goes up. In the whole series of years in the table there are only two in which the contrary is the case. In one of these the marriage-rate remained stationary, though the unemployed fell off in numbers; leaving in all the remaining nineteen years only one occasion in which the marriage-rate and the proportion of men out of work moved in opposite directions. Again, the five years in which the marriage-rate was lowest were 1879, 1885, 1886, 1887, and 1888, and in four of these years the proportion of men out of employ was highest. So also the five years in which the marriage-rate was highest were $1871,1872,1873,1874$, and 1875, and these were also the five years in which the proportion of unemployed was lowest.

The unions for which I was able to get the requisite data were very few in number, and represent a very limited range of indurstries; none of the great textile, nor the mining industries, nor the agricultural, nor the shopkeeping population being included, and the total number of members in the unions in no one year reached an aggregate of 125,000; and yet the fluctuations in the amount of employment in these few trades, and in this limited number of men, are found to be actually a very close index of the fluctuations in the marriage-rate of the whole country. This seems to me a most striking phenomenon, indicating as it does an amount of sympathy between all the various industries, for which I confess the familiar statement, that no one part of the social body can suffer without the rest also being affected, had not prepared me. But we may even go farther, and find still more striking evidence of this solidarity of industries, by taking a still smaller sample than is given by this limited number of trade unions, with their 1 25,000 members, and confining ourselves to a single, and that a very small union. Among the trade unions which form the little aggregate I have dealt with is the "Glass Bottle Makers of Yorkshire "United Trade Protection Society." In no one year has the number of members of this little society been as many as I,600; and yet I find that the fluctuations in the employment of this minute body of men correspond closely in their directions with the fluctuations in the marriage-rate of the entire country; so that the oscillations in the prosperity of this small trade become a faithful index of the prosperity of the country at large. How close the correspondence is may be judged from the fact that in the course of eighteen years, from 1870 onwards, only three times did the change in the marriage-rate of England and Wales fail to tally in its direction 
with the change in the amount of employment in this small local industry.

The conclusions then at which we arrive, so far as we have yet gone, are these: that the fluctuations in the marriage-rate follow the fluctuations in the amount of industrial employment; and secondly, that the various industries are so solidly bound together, that the changes in even a single and a small one afford a very close index of the changes in the whole of them.

Let us now go back for a moment to the price of wheat and its relation to the marriage-rate. I have shown that the ordinary statement that men marry when wheat is cheap is not true, at any rate for this country, and I said that as a matter of fact in recent years the very opposite has been the case, and that marriages have been most numerous when wheat has been dear, or rather that the marriage-rate has gone up when the price of wheat has increased. That men should be more inclined to burden themselves with a family at a time when the necessaries of life are dear, and less ready to do so when food is cheap, seems so paradoxical a statement, that it is necessary before seeking for its explanation to show that it is an actual fact. Let me then again call your attention to Table $\mathrm{A}$, where are given the marriage-rates and the price of wheat for a series of years, and let us confine ourselves to the years beginning with 1871. Since that date the average annual price of wheat has gone down on ten occasions below the price of the next preceding year, namely in 1874, 1875, $1878,1879,1882,1883,1884,1885,1886$, and 1888, and in no less than eight of these ten years the marriage-rate has followed suit; while in one (1888) of the remaining two years it remained stationary, thus leaving only a single occasion (1883) when wheat fell and marriages increased, and it will be noted that in that exceptional year the fall in wheat was excessively small, only $4 d$. per quarter. On the other hand there are eight years, 1871, 1872, $1873,1876,1877,1880,1881$, and 1887, in which the price of wheat rose above that of the preceding year, and in six of these eight years the marriage-rate also rose, 1878 and 1879 being the only exceptions.

Such a coincidence as this cannot possibly be only casual, and the apparent paradox of increased marriages with dearer food, and diminished marriages with cheaper food, requires explanation.

The explanation which I would offer is this. Men marry, as we have seen, in greater numbers when trade is brisk, and when the value of exports increases; but when the exports increase, so also do freights, and this rise in freights causes a corresponding rise in wheat, the largest part of our wheat being imported from abroad. The fact that the proportion of our wheat supply that is 
derived from abroad has been increasing, explains why it is that the direct relation between the marriage-rate and the price of wheat has been much more distinctly marked in recent years, say since about 1870 , than it was in earlier periods.

In conclusion then the marriage-rate rises and falls with the amount of industrial employment, which in its turn is determined by the briskness of trade, as measured by the values of exports, which also rise and fall concomitantly, and produce by their effect upon freights a simultaneous rise or fall in the price of wheat.

We have now to consider how it comes about that, while the fluctuations in commercial and industrial activity, as measured by the export values, produce corresponding fluctuations in the marriage-rate, the correspondence is, as we have seen, only in the directions and not in the proportional magnitudes of the waves these magnitudes differing indeed so enormously in the two cases, that the curves representing respectively the values and the rates come to have the utterly different contours shown in Diagram A.

In the first place it is manifest that a cause which only affects the prosperity of a part of the population, or affects the prosperity of one part to a greater extent than it affects the prosperity of the remainder, cannot possibly bring about waves in the marriage-rate of the whole body that will be proportionate in size to its own fluctuations; and the cause we have been considering, namely industrial and commercial activity, clearly affects the manufacturing much more than the agricultural classes. A change which doubled, let us say, or halved in any year the marriage-rate of the industrial classès, while it left untouched that of the agricultural classes, would clearly not double nor halve the marriage-rate of the whole population; and the degree in which it failed to do so would of course depend upon the proportions in which the industrial and the agricultural elements were represented in the aggregate population. The smaller the proportion of the agricultural element, the less interference would it cause, and the closer should be the correspondence between the fluctuations of the marriage-rate of the whole population and the fluctuations in the export values as measures of industrial prosperity. Now the proportion of the agricultural to the industrial element in this country has for many years been getting smaller and smaller, the rural population having remained stationary, or even slightly declined, while the urban or industrial population has enormously increased. Consequently we ought to find that the fluctuations in the marriagerate have been getting nearer and nearer into accord with the fluctuations in the export values; and if you look at the curves in Diagram A, you will see that this has in fact been the case. The curves up to somewhere about 1868 are as different in their 
general contour as can be, while in the years since then they have become recognisably similar in aspect. This increasing similarity is explained by the increasing preponderance of the industrial over the agricultural population.

It seems however scarcely probable that the great divergence of the marriage curve from the export curve can thus be adequately explained; and the divergence would seem to require for its explanation the existence of some constantly increasing influence which has tended to cause depression; and I think I shall he able to show, at any rate in an approximate manner, to what extent this unknown influence has acted in a downward direction for a series of years.

In 1888 the value of British exports per head of population was, as shown in Table A, 6l. $4 s$. I $d$.; and going back it will be seen that the value was practically the same in 1866 , the difference being only a few pence. Clearly then if the marriage-rate were determined simply by the export values, the rates should have been practically identical in these two years. But nothing of the kind was the case. The rate in 1866 was $17^{\circ} 5$ per 1,000 , while in 1888 it was only $14^{\cdot 2}$, a fall of $3 \cdot 3$. This fall then of $3 \cdot 3$ in the twentytwo years from 1866 to 1888, must have been due to something else than changes in export values, which remained unaltered. We have thus procured some kind of measure of the effect upon the marriage-rate of the supposed depressing influence which interferes with the action of the export values. It has reduced the rate by 3.3 in twenty-two years, and we may assume that consequently it would have caused a reduction of 4.65 in thirty-one years, that is in the interval going backwards between 1888 and 1857, which latter year I take as my starting point, as being the first year after the disturbance in rates caused by the Crimean war.

Let us assume that the unknown influence which caused this depression of $4^{\cdot 6}$ was something which acted from beginning to end of the period with regularly increasing effect, so that the depression due to it in the first annual interval was one thirty-first part of the 4.65 , in the second year was two thirty-first parts, in the third three, and so on until in the final or thirty-first year it caused the total fall of $4^{\cdot 65}$. This being assumed, we can of course correct the recorded marriage-rates for each of the thirty-one years, by restoring to it the amount by which it has been hypothetically depressed by the unknown influence, and when this is done, and the curve thus corrected has been graphically drawn out, that curve will of course hypothetically represent the fluctuation in the rates caused simply by the changes in the export vaiues, and if the hypothesis be true, the new curve should correspond much more closely than did the old and uncorrected curve, both in the 


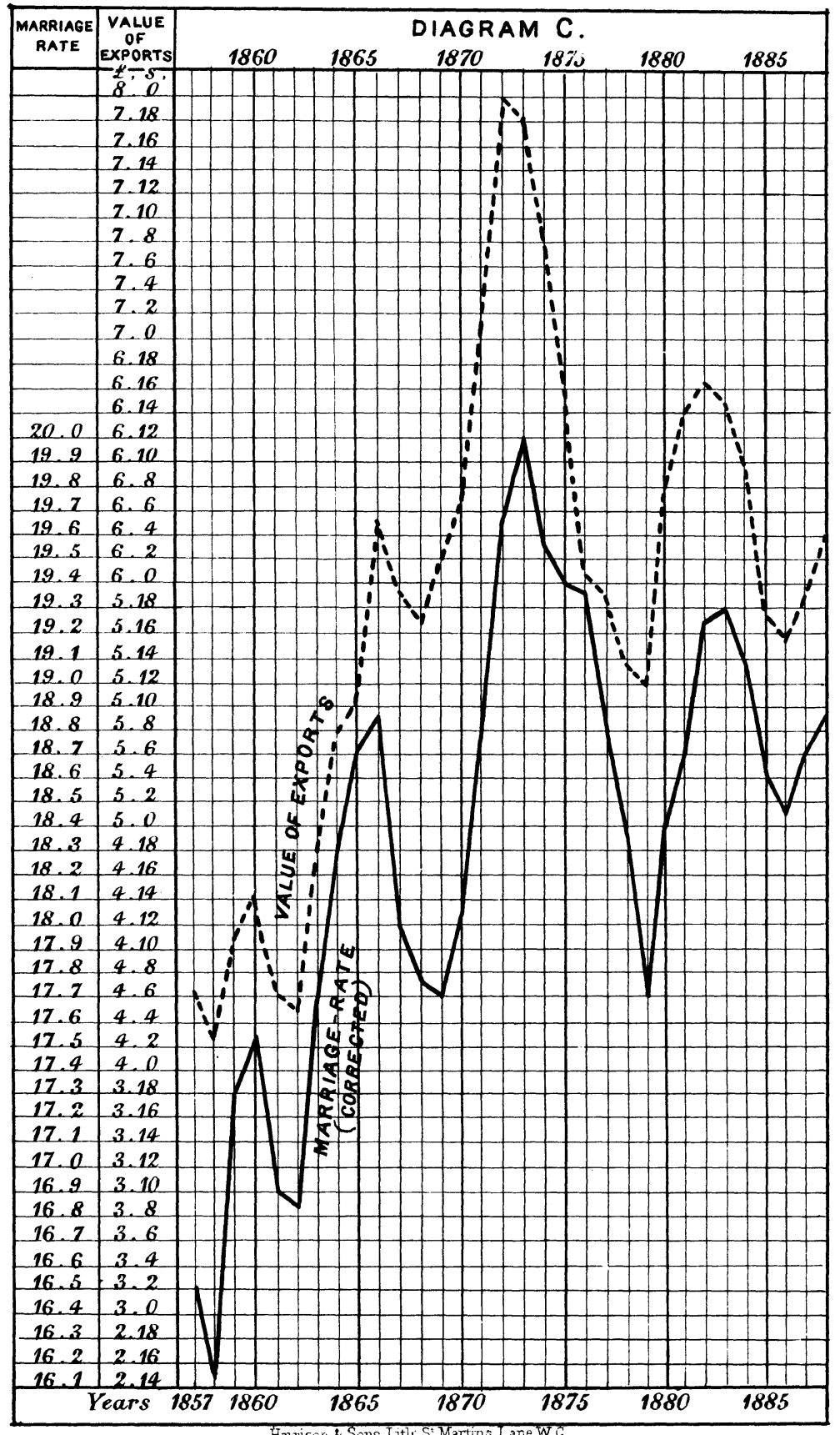

Hanrisod \& Sons. Litli. St. Martins Lane.W. 
direction and the proportionate size of its waves, with the curve of export values; and I need hardly add that, if that correspondence be found to exist, it will be very strong evidence indeed that the hypothesis of some constantly increasing depressing influence is true.

Let me then ask you to look at Diagram C, where the new curve, the curve that is of the rates corrected in the way described, is set side by side with the curve of export values, and I think you will agree with me that the required correspondence between the two does really exist. The two curves tally in the most remarkable degree with each other, in a degree which is certainly quite as close as could possibly be expected in so complex a matter as this ; and this close correspondence is, as I have already stated, irresistible evidence that the hypothesis by which the correction was made was a true one.

It appears then that for many years past there has been some cause in operation, which, in spite of the increasing wealth of the country, in spite of the increased value and the still more increased bulk of our exports, in spite of higher wages and cheaper commodities, has tended to make men more and more unwilling to venture upon marriage, and it would be highly interesting to know what this influence may have been. Possibly, and probably, it has been no one single cause, but an aggregate of causes that has had this depressing effect. I can but suggest two which have almost certainly contributed to the result, though I am far from asserting that it is to them that the whole has been due.

Firstly, there is the continued and the increasing depression in agriculture, which has rendered marriage less and less possible among those who depend for their livelihood upon the land; and secondly, there is-and to this I am disposed to attribute the main share in the matter-the ever-increasing standard of comfort among all classes, which makes men and women unwilling to burden themselves with a family until they are assured of a much ligher income than they would in former days have held to be sufficient. That the standard of living has vastly increased among the working classes, who form the great bulk of the population, no one, I think, will doubt who had the pleasure of hearing Mr. Giffen's papers read in this room; and that such a raising of the standard would lead to a retardation or abandonment of marriages, is self-evident. So that we have in this, and in the equally indisputable agricultural depression, two verce causee which must have produced part, and possibly may have produced the whole, of the depression for which we have been seeking an explanation.

Having now considered the causes of the fluctuations in the VOL. LIII. PAR'I II. 
marriage-rate in the whole kingdom, let us see what are the variations it presents in different parts of that kingdom.

The rates vary very greatly in the different registration counties, and the differences between one county and another in this respect present a very considerable degree of constancy from year to year. Thus, in Lancashire, Nottinghamshire, Northumberland, and in London the rate is invariably high, while in the extra metropolitan parts of Surrey, Middlesex, and Kent, as also in Essex, Hertfordshire, and Herefordshire, it is almost as invariably low.

Much of these apparent differences is merely due to the very great differences between counties in regard to the proportion of the unmarried men of marriageable ages in their respective populations; thus in some counties there is I such marriageable manbachelor or widower-for every 13 of the population, while in other counties there is but $I$ in every 20 . In order to make due correction for this diversity, it is necessary to calculate the marriage-rate not by the proportion of marriages to the total population, but by their proportion to the unmarried men of marriageable ages, which we may take as from 20 to 45 ; for though some few men marry before 20 , and others after 45 , we may neglect these as too few to be of material importance. But even when the rates are thus calculated, there are still vast differences left between the counties, as may be seen in Table $\mathrm{C}$, where the average rates thus calculated are given for each county for the ten years 1876-85. The counties are arranged in that table in order of their rates, and it will be seen that while in Bedfordshire, which stands at the top of the list, no less than I54 per I, 000 of the marriageable men marry each year, in Herefordshire, which stands at the other end, the proportion is only 80 , while the remaining counties range between these extremes in an apparently inexplicable manner, their manufacturing or their agricultural condition giving, so far as can be detected, no clue whatsoever to their relative positions in the list. 
TABLe C.

\begin{tabular}{|c|c|c|c|c|}
\hline \multirow{2}{*}{ Registration County. } & \multirow{2}{*}{$\begin{array}{c}2 \\
\text { Average Annual } \\
\text { Marriages per } \\
\text { r,o0 Unmarried } \\
\text { Men, } \\
\text { Aged } 20-45 \text { Years, } \\
\text { 1876-85. }\end{array}$} & \multirow{2}{*}{ 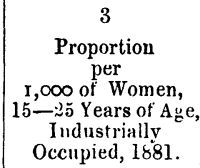 } & \multicolumn{2}{|c|}{$\begin{array}{c}4 \\
\text { Under } 21, \\
\text { per } 1,000 \text { Married. }\end{array}$} \\
\hline & & & Men. & Women. \\
\hline Bedfordshire $\quad$...................... & 154 & 701 & 147 & 226 \\
\hline Gloucestershire & 145 & 465 & 85 & 190 \\
\hline Nottinghamshire .................... & 14.2 & 557 & 124 & 290 \\
\hline Leicestershire .......................... & 140 & 628 & 126 & 252 \\
\hline 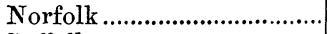 & 134 & 420 & 97 & 226 \\
\hline 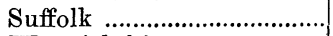 & 131 & 382 & 87 & 218 \\
\hline Warwickshire ........................... & 127 & 59.5 & 82 & 228 \\
\hline Somersetshire …...................... & 127 & 469 & 80 & 167 \\
\hline Huntingdonshire .................. & 126 & 370 & 92 & 216 \\
\hline Devonshire ….......................... & 125 & 416 & 65 & 144 \\
\hline Iondon & 124 & 534 & 53 & 183 \\
\hline West Riding & 123 & 600 & 96 & 262 \\
\hline 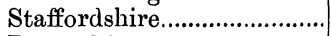 & 123 & 437 & 112 & 289 \\
\hline Lancashire & 122 & 671 & 88 & 226 \\
\hline Buckinghamshire ................. & 121 & 475 & 108 & 221 \\
\hline Northamptonshire & 120 & 507 & 114 & 240 \\
\hline 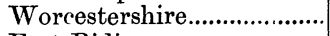 & 119 & 474 & 79 & 201 \\
\hline East Riding …........................... & 117 & 286 & 74 & 260 \\
\hline 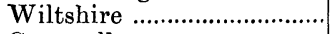 & 111 & $39 x$ & 74 & 175 \\
\hline 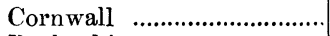 & 110 & 370 & 60 & 164 \\
\hline Derbyshire & 110 & 475 & 97 & 276 \\
\hline 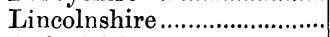 & 108 & 266 & 59 & $2 \mathrm{I} 4$ \\
\hline Oxfordshire & 108 & $3^{68}$ & 72 & 178 \\
\hline Sussex & 108 & 3.08 & 64 & 18.0 \\
\hline Chesbire & 107 & 504 & 76 & I94 \\
\hline Durham & 107 & 308 & 77 & 321 \\
\hline Northumberland ................... & 107 & 308 & 49 & 220 \\
\hline Dorsetshire & 106 & 429 & 65 & I 70 \\
\hline Cambridgeshire ….................. & 105 & 320 & 88 & 214 \\
\hline Monmouthshire & 104 & 308 & 73 & 241 \\
\hline 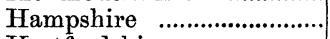 & 103 & 327 & 46 & 191 \\
\hline Hertfordshire ……..................... & 102 & 468 & 43 & 185 \\
\hline Essex & 101 & 332 & 75 & 226 \\
\hline Kent (extra met.) …........... & 100 & 280 & 59 & 218 \\
\hline 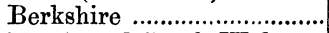 & 98 & 366 & 59 & 167 \\
\hline North and South Wales.... & 97 & 309 & 55 & 163 \\
\hline North Riding . ......................... & 93 & 231 & 63 & $25^{8}$ \\
\hline Rutlandshire & 92 & 261 & 38 & 160 \\
\hline Westmorland ........................ & 90 & 349 & 52 & I5y \\
\hline 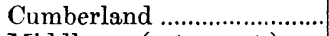 & 89 & 364 & 51 & 197 \\
\hline Middlesex (extra met.) .... & 89 & 302 & 50 & ז66 \\
\hline 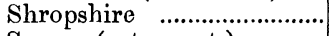 & 84 & 286 & 42 & 144 \\
\hline Surrey (extra met.) .............. & 84 & 291 & 43 & 155 \\
\hline Herefordshire .......................... & 80 & 289 & 43 & 142 \\
\hline
\end{tabular}

This fact has long puzzled me, but I think I have at last hit upon at any rate a partial explanation of the difficulty. Seeing the curious position held by Bedfordshire at the top of the counties, I was led to consider what were the special peculiarities of the population of this rural county, and the most notable 
feature in it appeared to be the great extent to which young women were occupied in the straw plaiting and the lace industries; and it appeared not impossible that the high marriagerate might be connected with this fact, as men might not unnaturally be more ready to marry girls or young women who were themselves earning money. In order to test this hypothetical explanation, I calculated, by means of the records of the census for 1881, the proportions of young women between 15 and 25 years of age that were returned in the several counties as engaged in some industrial occupation, domestic servants being excluded from this calculation as almost necessarily in a colibate condition. The results are given in Col. 3 of Table $\mathrm{C}$, and confirm generally the supposition from which I had started. For there is manifestly a very remarkable degree of correspondence between the marriagerate as given in Col. 2, and the proportion of young women earning money in industrial occupations as given in the next column. The correspondence is by no means perfect; that is more than could possibly be expected; for no one can suppose that the only factor in determining the number of marriages is the power of the woman to contribute by her earnings to the household expenses. There are of course other factors, such as the amount of male employment and wages, and probably other local circumstances and customs are operative; but it is, I think, impossible to doubt on examining the figures that one very powerful factor in determining the marriage-rate is the degree in which women find industrial occupations. Almost all the counties in which the marriage-rate is high, are counties in which the proportion is also high of women engaged in industrial occupations, and therefore presumably in receipt of independent earnings; while all the counties at the other end of the list, all those counties that is in which the marriage-rate is very low, are also counties in which but a very small proportion of the women are industrially occupied. Thus of the seventeen counties that come first in the lists, that is to say, the seventeen counties in which the marriagerates are highest, there is only one, viz., Suffolk, in which the proportion of young women engaged in some other industry than domestic service is ander $4 \mathrm{r} 6$ in the 1,000 ; while of the sixteen counties at the other end of the list, of the sixteen counties that is in which the marriage-rates are lowest, there is only one, viz., Hertfordshire, in which the proportion of young women with independent occupations is as high as this. Doubtlessly there are many exceptions to this general statement, such as Norfolk and Suffolk, which stand much higher in the list, and Lancashire and Cheshire, which stand much lower than would have been expected. Still the general drift of the figures is, I think, unmistakeable, and 
lead to the conclusion that marriage is, on the whole, most common where there is the largest amount of employment for women.

From time to time one comes across laments on the unhappy condition of women, who are represented as driven to matrimony because they are unable by any other means to support themselves. This doubtlessly may sometimes be the case, especially in the classes where women are not taught any remunerative art; but among the working classes the very opposite is the case, and those women who are industrially occupied, and therefore, on the whole, best able to maintain themselves, are those who are most likely to marry.

Marriages then are on the whole more numerous in those counties where women are earning independent wages; and the question naturally suggests itself whether women also marry at earlier ages in these counties. The only means we have of judging as to this is by considering the proportion of brides who are under age at the time of marriage in the several counties; and judging by this standard, it would seem that to some extent women who are earning independent wages do marry at an earlier age, but not to so great an extent as might have been anticipated. In most of the counties where the proportion of occupied young women is high, the proportion of under-age brides is also more or less above the average, and in most of the counties where the proportion of occupied women is low, the under-age brides are also comparatively few. But there are many exceptions, and especially notable in the case of Durham, where the proportion of occupied young women is very low, and yet the under-age brides are far more numerous than elsewhere (Table C, Cols. 3 and 5). The age of the brides seems to be much more determined by the earnings of the husband than by her own. It is in the mining or great industrial centres, in Durham, for instance, in Derbyshire, Staffordshire, the West Riding, and Nottinghamshire, in the counties that is where men are on the whole in receipt of high wages, that women marry youngest; and as the man when in receipt of comparatively high wages marries a very young wife, so would it appear that when women are in receipt of independent earnings they are inclined to wed with youthful husbands; for it is in the counties where the proportion of such women is high, that the proportion of under-age husbands is on the whole the highest. T'hus in Bedfordshire, with the highest proportion of industrially occupied young women, the proportion of under-age husbands is also highest; while Nottinghamshire and Leicestershire, which come third and fourth in the list in Table $\mathrm{C}$, are also the two counties in which after Bedfordshire these under-age husbands are most numerous. 
And now, before leaving the subject of marriage-rates, a few words as to the relation between this rate and the growth of the population.

The population of England and Wales is, as we all know, growing in a most formidable manner; and though persons may differ in their estimates of the time when thac growth will have reached its permissible limits, no one can doubt that, if the present rate of increase be maintained, the date of that event cannot possibly be very remote. The birth-rate, it is true, has of late years fallen greatly, but so also has the death-rate, and almost in equal amount; so that the balance between the two, or natural increment of the population, has practically scarcely changed. Hitherto some of the excess of births over deaths has been met by emigration, or rather by excess of emigration over immigration; but, without insisting on the fact that this remedy has never yet been on such a scale as to free the country of more than one-twentieth part of its redundant growth, or on the further fact that the remedy is one which is perpetually carrying off the more vigorous and enterprising of our working men, to the necessary deterioration of the residue left at home-without, I say, insisting on these facts-it is plain that the facilities for successful emigration are yearly diminishing, and that the time must inevitably come-sooner or later-when this means of reducing our population will altogether fail us. When that time shall have arrived, and the limits of the means of subsistence shall have been reached, in some way or other the birth-rate and death-rate will have to be equalised, so that the population, having reached its permissible magnitude, may remain stationary. This equalisation can clearly only be effected either by increase of mortality or by diminution of the birth-rate; and as no one will advocate the former, the problem of problems, which even now is vexing the souls of those who can look beyond the immediate fature, is how the birth-rate is to be reduced. The only aspect of this question with which $I$ am at present concerned is the extent to which it would be necessary to reduce the marriagerate if the equalisation of births and deaths were left simply to that agency. The calculation is of course easy. The death-rate in 1888 had fallen to 17.8 per 1,000 , and, as we trust that sanitary supervision will at any rate ensure for us the continuance of such a degree of healthiness as has been already attained, the birth-rate must, if equalisation is to be effected, be reduced to the same figure. Now the illegitimate birth-rate in 1888 was $1_{4} 4$ per 1,000 , being at its minimum, and we can hardly expect that when marriages are reduced there will be any decline in this figure; so that the legitimate birth-rate must not amount to more than $16^{\circ} 4$ per $1, \infty 00$. To what marriage-rate would a birth-rate of 16.4 correspond? 
The average number of children born to a marriage in this country is about $4^{\cdot 2}$; and so long as the ages at which women marry do not materially change, this may be taken as a constant measure of fertility. Indeed so long ago as 1665 it was estimated by Captain Graunt in his often cited treatise, " that every wedding, one with " another, produces four children." With $4^{\circ} \mathbf{2}$ children to a marriage, the marriages which would give a legitimate birth-rate of 16.4 would be 3.9 per 1,000 , which, as there are two parties to a marriage, gives a marriage-rate, in our English mode of stating it, of 7.8 per 1,000 .

This then is the marriage-rate necessary to produce a stationary population, supposing the present mortality not to increase, nor other changes, such for example as advance in the ages at which marriage is contracted, to occur. Now the lowest point to which the marriage-rate has ever yet fallen has been $14^{*} \mathbf{I}$, so that, if the growth of the population is to be stopped by mere reduction of marriages, the rate must fall 45 per cent. below the lowest point which it has ever yet touched, or, roughly speaking, nearly one-half of the persons who now marry must remain permanently celibate.

I confess that, seeing what human nature is, and how much more operative is the prospect of personal and immediate satisfaction than the fear of damage to the interests of future generations, I cannot entertain any hope that the remedy for undue growth of the population will ever be found in an adequate reduction of the marriage-rate. How far the end may be obtained not by absolute celibacy, but by retardation of marriage to later ages, will be presently considered.

From marriage-rates let us now pass on to marriage-ages, a subject of scarcely less importance than the rates in its bearing upon the growth of the population.

In Table $\mathrm{D}$ are given the average ages at marriage of bachelors and spinsters for each year from 1867 to 1888, and it will be there seen that the average age of the bachelors has been throughout either slightly below or slightly above 26 years, while that of the spinsters bas been somewhat over 24; ages respectively very far removed from those held to be most advantageous by the ancients, who laid down that the best age for the wife was 18 or 19 , while the husband should be, according to Hesiod, about 30, and according to Aristotle, as much as 37 years of age. But in those days population was scanty, and mortality was high, and the ideal aimed at was that conjunction which would result in the largest number of healthy children to meet the incessant devastation of war and pestilence.

5 "Observations on the Bills of Mortality," \&c., 5th edit., p. 97. 
TABLE D.

\begin{tabular}{|c|c|c|c|c|c|}
\hline \multirow{2}{*}{ Year. } & \multicolumn{2}{|c|}{ Average Age at Marriage. } & \multirow{2}{*}{ Year. } & \multicolumn{2}{|c|}{ Average Age at Marriage. } \\
\hline & Bachelors. & Spinsters. & & Bachelors. & Spinsters. \\
\hline 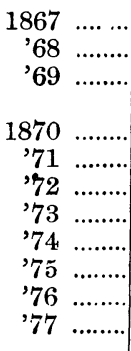 & $\begin{array}{l}25 \cdot 8 \\
25.8 \\
25 \cdot 8 \\
\\
25 \cdot 8 \\
25 \cdot 8 \\
25.7 \\
25.6 \\
25.7 \\
25 \cdot 7 \\
25.7 \\
25.7\end{array}$ & $\begin{array}{l}24 \cdot 5 \\
24 \cdot 4 \\
24 \cdot 4 \\
\\
24 \cdot 4 \\
24 \cdot 4 \\
24 \cdot 3 \\
24 \cdot 2 \\
24 \cdot 3 \\
24 \cdot 3 \\
24 \cdot 4 \\
24 \cdot 4\end{array}$ & 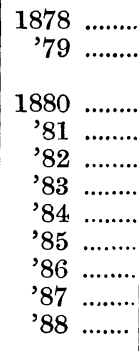 & $\begin{array}{l}25 \cdot 8 \\
25 \cdot 8 \\
25 \cdot 8 \\
25 \cdot 9 \\
25 \cdot 9 \\
25 \cdot 9 \\
26 \cdot 0 \\
26 \cdot 1 \\
26 \cdot 2 \\
26 \cdot 2 \\
26 \cdot 3\end{array}$ & $\begin{array}{l}24 \cdot 4 \\
24 \cdot 3 \\
\\
24 \cdot 4 \\
24 \cdot 4 \\
24 \cdot 4 \\
24 \cdot 4 \\
24 \cdot 5 \\
24 \cdot 6 \\
24 \cdot 6 \\
24 \cdot 7 \\
24 \cdot 7\end{array}$ \\
\hline
\end{tabular}

It will be seen, on examining the table, that the average age at marriage of both bachelors and spinsters is liable to fluctuation, and on comparing the ages in the twenty-two successive years included in the table with the corresponding marriage-rate, it will be noted that the lowest average age for both bachelors and spinsters was in 1873, the year in which the marriage-rate was highest, and that from that date to the present time the ages have gone up gradually but progressively in harmony with the general decline in the marriage-rate; so that it would appear that in times of industrial activity not only are marriages more numerous, but they are contracted at earlier ages than in less prosperous periods, and that in bad times not only do fewer persons marry, but those who do marry are on the whole of riper years.

The same fact is shown in another table (Table $\mathrm{E}$ ), in which the annual marriage-rates are given for different ages for 1851 and for 1880-82. In this interval of thirty years, the marriage-rate fell from $17^{\cdot 2}$ to $15^{\cdot 2}$; but the table shows that this decline was entirely brought about, so far as bachelors are concerned, by a decline in the marriages of those between 20 and 25 years of age, and that bachelors older than this actually married at the later date in higher proportions than before; and something of the same kind is visible, though not quite so distinctly, in the case of the widowers, the spinsters, and the widows, that is to say in each of these groups the decline in marriages was less in the advanced than in the earlier ages, and indeed in the very advanced ages the rate in all cases rose. 
Table E.-Annual Marriages per 1,000 Living at each Period of Life.

\begin{tabular}{|c|c|c|c|c|c|c|c|c|}
\hline \multirow{2}{*}{ Ages. } & \multicolumn{2}{|c|}{ Bachelors. } & \multicolumn{2}{|c|}{ Spinsters. } & \multicolumn{2}{|c|}{ Widowers. } & \multicolumn{2}{|c|}{ Widows. } \\
\hline & 1851. & 1880-82. & 1851. & 1880-82. & 1851. & $1880-82$ & 1851. & 1880-82. \\
\hline $15-\ldots . .$. & $4^{\cdot 6}$ & $4 \cdot 6$ & $2 \mathrm{I} \cdot 8$ & $21 \cdot 5$ & - & - & $50^{\circ} 0$ & $56 \cdot 6$ \\
\hline $20-\ldots \ldots$. & II $2^{\circ} I$ & $106 \cdot 8$ & 126.7 & $121 \cdot 9$ & $307 \% 7$ & $193 \cdot 0$ & 196.5 & $155 \cdot 3$ \\
\hline $25-\ldots \ldots$ & $107 \cdot 2$ & $112 \cdot 4$ & $82 \cdot 9$ & $80 \cdot 6$ & $312 \cdot 6$ & 246.5 & 127.7 & $114: 6$ \\
\hline $35-\quad \ldots . .$. & $38 \cdot 3$ & $40 \cdot 5$ & $32 \cdot 5$ & $26 \cdot 3$ & $167 \cdot 6$ & $157 \cdot 8$ & $55^{\circ} 4$ & $50 \cdot 2$ \\
\hline $45-\ldots . .$. & II $\cdot 2$ & $14: 3$ & 104 & $10 \cdot 4$ & $7 I^{\circ} I$ & $76 \cdot 9$ & $19^{\circ} 0$ & $18 \cdot 6$ \\
\hline $55-\ldots \ldots$. & $2 \cdot 6$ & $4 \cdot 4$ & $2 \cdot 6$ & $2 \cdot 5$ & $23 \cdot 8$ & $33 \cdot 9$ & $4 \cdot 5$ & $5 \cdot 4$ \\
\hline $65-\ldots . .$. & 0.8 & $1 \cdot 0$ & 0.2 & 0.4 & $3 \cdot 8$ & $6 \cdot 0$ & 0.3 & 0.6 \\
\hline All ages ... & $57 \cdot 7$ & $55 \cdot 8$ & $60 \cdot 8$ & $56 \cdot 9$ & $64 \cdot 6$ & $58 \cdot 2$ & $21^{\circ} \mathrm{O}$ & $18 \cdot 2$ \\
\hline
\end{tabular}

The mean marriage-age then has for a long series of years, ever since 1873 , been gradually increasing; marriages have been getting fewer and fewer, and those who have married have been each year older and older. But the entire change after all has not been very great. In 1873 the bachelors averaged 25.6 and the spinsters $24 \cdot 2$ years of age, and that was for each the minimum; while in 1888 the ages had risen respectively to $26 \cdot 3$ and $24 \cdot 7$, and these were each the maximum; so that the whole change has been an addition of six months to the average age of the spinsters, and of about eight months to the average age of the bachelors. It must not however be assumed that such an addition is unimportant. An average difference of six months in the age at marriage would mean for the 204,000 marriages which were contracted in 1888 a lessening by 102,000 years of the aggregate amount of cohabitation of those who married in that year, and this repeated annually would possibly mean a very considerable reduction in the growth of the population. Whether it does so or not we shall see presently.

But if the average age at marriage varies but little from year to year, it is not so with the marriage-ages in different classes, as is very clearly to be seen in the two following tables (Tables $F$ and $G$ ), in the former of which are given the mean ages at marriage of bachelors and spinsters in different occupational groups, while the other gives the age-distribution of bachelors and spinsters in the several groups at the time of marriage. 
Table F.-Average Ages at Marriage, 1884-85.*

\begin{tabular}{|c|c|c|}
\hline Occupations. & Bachelors. & Spinsters. \\
\hline 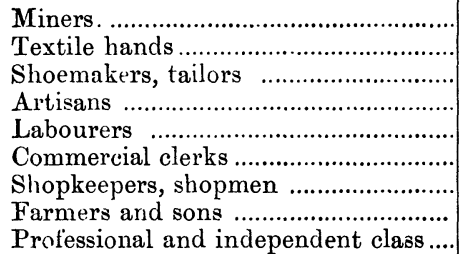 & $\begin{array}{l}24 \cdot 06 \\
24 \cdot 38 \\
24 \cdot 92 \\
25 \cdot 35 \\
25 \cdot 56 \\
26 \cdot 25 \\
26 \cdot 67 \\
29 \cdot 23 \\
31 \cdot 22\end{array}$ & $\begin{array}{l}22.46 \\
23 \cdot 43 \\
24.31 \\
23.70 \\
23^{\circ} \cdot 66 \\
24^{\circ} 43 \\
24 \cdot 22 \\
26^{\circ} \cdot 91 \\
26.40\end{array}$ \\
\hline
\end{tabular}

* The age-distribution of the men employed in the different occupations differs much; and this would, if uncorrected, of course cause some difference in the mean marriage-ages of the groups. To meet this difficulty, so far as possible, in the professional and independent group were included students of law, medicine, theology, \&c., as also all men described simply as gentlemen; so also with shopkeeper's were included shopmen, and with farmers their sons or other near relatives living with them. As to these and other precautions taken to make the groups as fairly comparable as possible, see forty-eighth (p.ix) and forty-ninth (p. viii) annual reports.

TABLe G.-Age-Distribution per $\mathrm{1}, 000$, of Bachelors in different Occupations, and of their Wives, at time of Marriage.

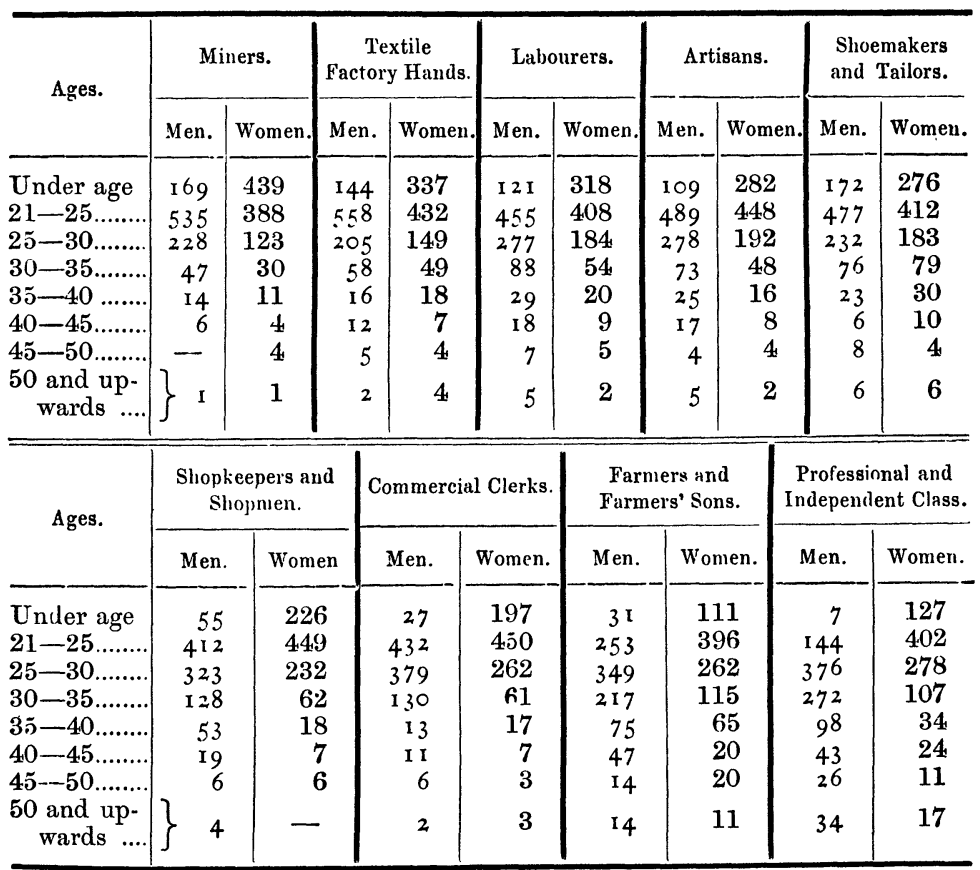


These tables are based upon samples taken by me from the marriage registers of 1884-85. The samples were of considerable size; still it is quite possible that had they been larger, and had they extended over a greater number of years, the figures might have been somewhat different, though it is scarcely possible that they would have been materially altered. They show at any rate with sufficient clearness that the ordinary belief that the lower the station in life, the earlier the age at which marriage is contracted, is true, and that the difference in this respect between the upper and the lower classes is very great indeed. It will be enough if we take a single example, and compare miners, for instance, with the professional class. Of the miners who marry, 704 in 1,000 are under 25 years of age; of the professional and independent class only I $5^{1}$; while the miners' wives, 827 , and of the upper classes only 529 , per 1,000 are under that age. The average marriage-age of the miners is 24 , and of their wives $22 \frac{1}{2}$ years; while the ages for the professional and independent class are respectively 31 and $26 \frac{1}{2}$ years; a difference of seven years for the husbands and four years for the wives.

The table of mean ages has already appeared in the fortyninth annual report of the registrar-general, and has been often quoted since; but, whenever I have chanced to see it cited, I have been somewhat surprised to find that the ages for the men were alone given, and no notice taken of the respective ages of the wives. It appears however to me that the ages of the men at marriage are, so far as concerns the growth of popalation, of comparatively small importance. For there is no reason whatsoever, so far as I am aware, to suppose that retardation of marriage in the case of men, of course within reasonable limits, will materially affect the number of their offspring, excepting that the older a man is when he marries the older will also be probably his wife, and further, that the older he and she are at marriage, the greater somewhat will be the chance that either he or she will die before the child-bearing period is fully completed. But independently of these considerations, there is, as I say, no reason to believe that a man who marries at 30 will have a smaller family than a man who marries at 20 , so long as the two wives are of one and the same age. Doubtlessly in the long run the wives in the two cases will not be of one and the same age, for as Table $\mathrm{H}$ shows, though older men usually marry older wives, they do not marry wives older in proportion to their own greater age. So far then as increase in population goes, the matter of importance is the age of the wife, not of the husband; and any material diminution in the growth of the people that is to be looked for from retarded marriage, must be obtained by retarding the marriages of women, 
not those of men. If greater age on the part of the husband were to have this effect, the ancient writers whom I have already quoted, who desired above all things the rapid growth of the population, would have been in serious error in proposing that the age of the husband should be 30 or 37 years; but as a matter of observation they were well aware that the age of the man had but little to do with the number of the progeny, while the age of the wife was of considerable importance, and this, as we have seen, was put by them at 18 or 19 .

As regards men, it is not the age at which they marry that is of importance, but the question whether they marry at all, and I have consequently tried to make some estimate of the relative proportions in which men in different classes of life altogether abstain from matrimony. The method I employed was to go through a large number of the census enumeration books, and ascertain what proportions of labourers and artisans, of shopkeepers, and of professional and independent men, in 1881, were still bachelors when they had reached the mature age of 50 years. I expected to find that the proportion would be smallest among the artisans and labourers, and highest in the professional and independent class; but as a matter of fact it turned out that it was among the shopkeepers that the proportion of confirmed bachelors was far the lowest, as probably, with more thought given to the subject, might have been anticipated, seeing that to a shopkeeper a wife is often almost a business necessity. Next to the shopkeepers, but a good way from them, came the artisans and labourers; while far ahead of all were the professional and independent class, with a proportion of permanent bachelors far above the rest. What is true of the men in these several groups is probably also true of the women, but I have no statistical evidence of this. I find however testimony to that effect given by those who are conversant with the habits of working women. Thus Miss Collett, writing ${ }^{6}$ of the east end of London, says, "every girl in the lowest "classes can get married, and with hardly any exceptions every "girl does marry. This is not true of the middle classes." It thus appears that in the upper classes not only do a larger proportion of persons remain throughout life unmarried, but those who do marry, marry at a much more advanced age than is the case with the rest of the population.

Now in the professional and independent classes the average age at marriage of the women is nearly $26 \frac{1}{2}$ years, and it would be of interest to know what would be the result as regards the birth-rate, if the women in all classes could be induced to retard their marriages to the same extent as do the women of the upper classes.

- "Labour and Life of the People," p. 472. 
But, for the sake of somewhat simplifying the question, let us inquire how far the growth of the population would be reduced if all women who marry within the childbearing ages were to marry five years later than they do now.

I think the ordinary notion of persons who have not thought about the matter will be that if 1,000 women marry at 20 , and a second I,000 marry at 25, the children born to the latter will be fewer than the children born to the former by as many children as these give birth to in the interval between their 20th and the end of their 25th year. But this is far from being the case. A woman who marries at 20 will, on the average, come to the end of her childbearing at an earlier age than the woman who marries later, say at 25. For the cessation of childbearing is determined not simply by the actual age, but also in part by the length of time that has elapsed since childbearing began. In short, fertility exhausts itself by its own activity.

What we have first to do is to ascertain what number of children are born on an average to women who marry at different ages. I can find no data for the direct determination of this. But there are data which will, I think, enable us to arrive at a sufficiently approximate result in an indirect manner.

The basis on which I build is a table in Dr. Duncan's treatise ${ }^{7}$ on fecundity, in which are given the percentages of wives married at various ages, who were still bearing children after five, ten, fifteen, \&c., years of married life. That table supposes the wives to remain alive throughout the periods in question. But as a certain number of them will die, or will lose their husbands, before the childbearing period is completed, it was necessary first of all to correct the figures for these chances.

The life table used by me for this purpose was that which I constructed from the death returns of $1871-80 ;^{8}$ and the husbands' ages, for wives married at different ages, were calculated from the data in the fiftieth annual report of the registrar-general, to be as follows :-

TABLE H.-Average Ages of Husbands at Marriage to Wives of various

\begin{tabular}{|c|c|c|}
\hline $\begin{array}{l}\text { Marriage-Age } \\
\text { of Wife. }\end{array}$ & \multicolumn{2}{|c|}{$\begin{array}{l}\text { Average Marriage-Age } \\
\text { of Husband. }\end{array}$} \\
\hline $15-20$ & ........ & $23 \cdot I$ \\
\hline $20-25$ & ........ & $25^{\circ} \mathrm{I}$ \\
\hline $25-30$ & ..... & $28 \cdot 6$ \\
\hline $30-35$ & ....... & $33^{\cdot} 8$ \\
\hline $35-40$ & ....... & $39^{\circ} 2$ \\
\hline
\end{tabular}

"Cf. " Fertility, Fecundity, and Sterility," 1866, p. 148.

$8 C f$. "Supplement to the Forty-Fifth Annual Report of the Registrar-General," pp vii and viii. 
The corrections having been made, the following table was obtained, which gives the percentage of wives married at various ages who remain alive, with living husbands, and still fertile, after various periods of years :-

\section{TABLE $I^{9}$}

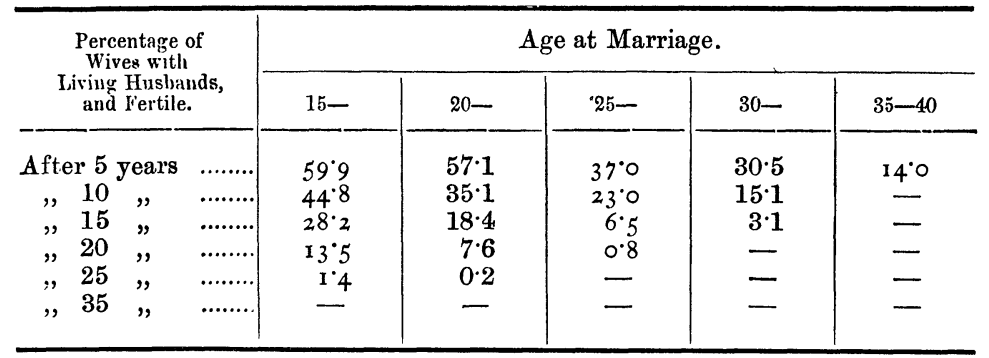

We may fairly assume that those wives who had ceased to be fertile, or had died, or lost their husbands, after five years from the date of marriage, had on the average been fertile for two and a half years; while those who continued their childbearing later, but had ceased when ten years were past, had been fertile for seven and a half year's, and so on with the other periods; and assuming this, we can easily calculate the average period of fecundity for wives married at different ages. They are as follows :-

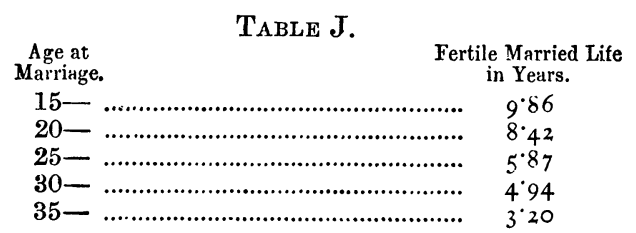

Now, the age-distribution of women who were at the time of marriage within childbearing ages, which, disregarding the few exceptions, we may take as terminating at 40 , was as follows in 1856-88, and the proportions are sufficiently constant for our purpose :-

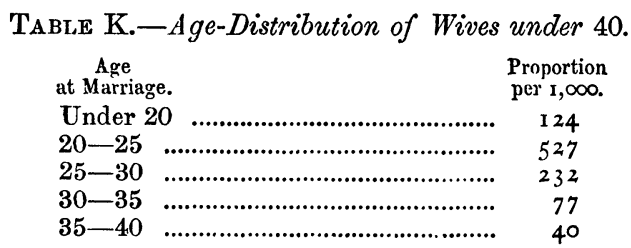

9 Table $I$ is to be read in the following way: Of roo women married when under 20 years of age, $59^{\circ} 9$ were still alive, with living husbands, and fertile, after five years of married life, $44^{\circ} 8$ were so after ten years, and so on. 
Combining these figures with those given in Table $\mathrm{J}$, it will be found that the average duration of fertile marriage life for women within childbearing ages is, with the present ages at marriage, $7^{\circ} 53$ years; and that, if all these women delayed their marriages for five years, the average duration of fertility would be reduced to $5^{\circ} 53$ years, or by 26.6 pex cent.

What effect would this have upon the birth-rate? We can scarcely be far out if we assume that a reduction of 26.6 per cent. in the average duration of childbearing would cause a corresponding reduction in the average number of children to a marriage; in which case that number, which is now 4.2 , would fall to $3 \cdot r$. With a marriage-rate of $14 . r$, which is the lowest as yet recorded, this would give a legitimate annual birth-rate of $2 I^{\circ} 9$ per $I, 000$, to which must further be added $I^{\cdot} 4$ for the illegitimate birth-rate, which, as already stated, is scarcely likely to fall lower than its present level if marriages are in any way hindered.

So that finally we arrive at the conclusion that in the very improbable event of all women retarding their marriages for five years, we should have a birth-rate of 23.3 per I, , ० ; doubtlessly a very great diminution of the present rate, but still far too small a diminution to produce anything like an equalisation of births and deaths, the death-rate having fallen, as we have seen, in 1888 to 17.8. The population would still be growing at the rate of between 5 and 6 per I,000 annually.

In order therefore to produce a stationary population, the ages of women at marriage would have to be advanced by considerably more than five years; and when we reflect that in the whole series of years for which we have the figures (Table D) the average age of brides has only increased by some six months, we may, I think, dismiss altogether the notion that any adequate check to the increase of population is hereafter to be found in retardation of marriage. Such retardation may defer the day when a stationary population will be necessary, but, when that day has come, will be insufficient to prevent further growth.

Now it has already been shown that, if a stationary population is to be obtained by simple diminution of the marriage-rate, that rate would have to be reduced 45 per cent. below the lowest point it has ever yet reached, or, in short, that almost one-half of those who marry would have to remain permanently celibate. This seems almost as hopeless a remedy as the retardation. But how if the two methods are combined? The calculation is easily made. With an average of $3 \cdot 1$ children to a marriage-that being the average which would result from a retardation of marriages for five years-a marriage-rate of 10.6 per I,000 would give a legiti- 
mate birth-rate of ${ }_{16} 6_{4}$, which, with $\mathrm{I}_{4}$ for the illegitimate rate, would give a total birth-rate of $17 \cdot 8$, which is also the death-rate of 1888; or, to express this in other words, if one-quarter of the women who now marry were to remain permanently celibate, and the remaining three-quarters were to retard their marriages for five years, the birth-rate would be reduced to the level of the present death-rate.

In conclusion then it is manifest that if the growth of population is hereafter to be arrested, and a stationary condition produced, either by emigration, or by increase of permanent celibacy, or by retardation of marriage, these remedies will have to be applied on a scale so enormously in excess of any experience, as to amount to a social revolution.

\section{Discussion on Dr. Ogle's Paper.}

Mr. F. Hendriks, Vice-President, said the paper was a most elaborate and interesting one, but it so bristled with problems that a great many questions might be put upon it. $\mathrm{He}$ wished to ask Dr. Ogle why he had placed the value of British exports per head of the population as the test of the commercial activity of the country. Why had he not included the imports as. well? If imports were included the figures for 1888 would be nearly trebled. There could be no doubt that the imports and the domestic industry of the country contributed as much to the commercial activity as the exports, and therefore to a large extent Table A was deficient in that respect, as well as from its taking no account of production for home use, or of inland consumption and trade. In computing the marriage-rate from 1820 to 1868 , had any allowance been made for the variations which had occurred in the distribution of the population according to the variations which were always arising in the proportions of the marriageable ages? If Dr. Ogle had merely taken the collective total population at each of the census periods, then, inasmuch as the relative and comparative numerical importance of the younger population of the country had been increasing from augmented births, low death-rate, and from emigration of adults, there might be very great discrepancies in arriving at the precise figures of the fluctuations in the marriagerate. In his criticisms on Dr. Farr's researches on this question, had Dr. Ogle given sufficient consideration to the fact that Dr. F'arr was writing as long ago as 1846, and consequently only had experience of a very different state of things from that which was now possessed? Dr. Farr had only the experience of the years between 1820 and 1846. At that time the average price of wheat in this country was a very much more important factor in the 
expenditure of the working classes than it could be now. Of course there were some foreign supplies of wheat and flour in 1846 , but they were not more than one-ninth of the present importations of these articles of food, and therefore the fluctuations in the average price of wheat in England were then of greater importance than they have been subsequently. He thought Dr. Ogle was mistaken in supposing that Dr. Farr was in error in saying that cheap food, particularly if accompanied with cheap lodging and clothing, and with improved wages, meant an increase of the marriage-rate. It was in the nature of things that it should be so. John Stuart Mill, too, did not say that cheap food was the only factor, as he also spoke of full employment. Mr. Fawcett's opinion was expressed in a brief manual of political economy in which he could not go into any minute explanations. $\mathrm{He}$ (Mr. Hendriks) bad some doubts about the accuracy of the statement in Dr. Ogle's paper in which freights were referred to as necessarily rising when there was a briskness of trade. That depended upon exceptional circumstances, because competition governed freights as well as prices. He rather thought it was also a mistake for Dr. Ogle to deprecate any other comparison than that of one year with the preceding or following year. A comparison between groups or averages of years might be more instructive. For example, if the years which followed on the gold discoveries from 1850 to 1866 were taken, it would be clearly seen, as written largely in the figures, that the marriage-rate had increased from the commercial prosperity of England having gone so much ahead during that period. The marriage-rate in 1851-66 averaged 169 per mille, whilst during the whole sixty-nine years $1820-88$ it averaged only $16 \cdot 2$ per mille. There was during that time which followed the Australian and Californian gold discoveries, a recrudescence of the average beyond the highest point of the initial period, and it was a matter for consideration whether an average drawn through the whole of the sixty-nine years covered by Dr. Ogle's table, namely, s6.2 per mille, would not represent the normal rate below which in long periods, sometimes of advance, and at other times of decline, in our national prosperity, the marriage-rate could hardly be expected to decline. He was afraid it was only a small fringe of the labouring classes who were guided by any consideration of what might occur after their own lives. It was very natural that those in the lower stages of society should cultivate the present moment, and not look much ahead. At the same time the old economists must not be blamed as if they had neglected to call attention to this. Such was by no means the fact. For example, one of the earliest members of this Society, Malthus, in his great work, the first edition of which appeared so long ago as in 1798, said that all that could be hoped for as a check to too early marriages was that the lower classes of the people should continue to improve in knowledge and prudence. The same language was used by John Stuart Mill, who said that nothing but moral compulsion, by which he meant the considering by the labouring classes of the consequences of their entering into marriage responsibilities at too early an age, would provide a remedy, as a guarantee of subsistence could only

VOL. LIII. PART II. 
thus be kept up practically when work is enforced and superfluous multiplication restrained.

Mr. H. Moncreiff Padl did not think it fair to make a comparison between the average price of wheat and the marriage-rate with a view to drawing conclusions such as Dr. Ogle had done. The "Gazette" average quoted by him was merely the average of English wheat, obtained in a particular way. It was not the average price of all the wheat sold or consumed in this country. The importations of wheat of late years has been very much greater than those of the earlier years reviewed in the paper, and it followed that the prices shown in the tables for later years could not be so great a factor as formerly in determining the value of wheat consumed. In order to take a test from the standard of provisions, it would be necessary to have statistics of all the other products that go to form the food of the masses of the people, such as meat, vegetables, dairy produce, tea, sugar, \&c. But even if that were done, the figures given would have an unimportant bearing in regard to a certain proportion of the middle and upper classes. He therefore thought that wheat statistics per se could not be accepted as any true test. Nor was it fair to take the exports per head without the imports as a test, and even if both were taken, a considerable amount of correction would be necessary, for the simple reason that the prices were annually of a fluctuating character. Were it possible to make a comparison by quantities, a more accurate result would be arrived at. He found that in the Australasian colonies it was equally impossible to derive any accurate conclusions over a series of years from a comparison of the marriage-rate with the value of exports per head of the population. There not only were provisions uniformly cheap, but there was little pauperism. But the following table, which he had prepared from official sources, for the decade ending in 1888 , showed that no conclusions could be formed as to any ultimate connection over that period between a high marriage-rate and a high export value por head:-

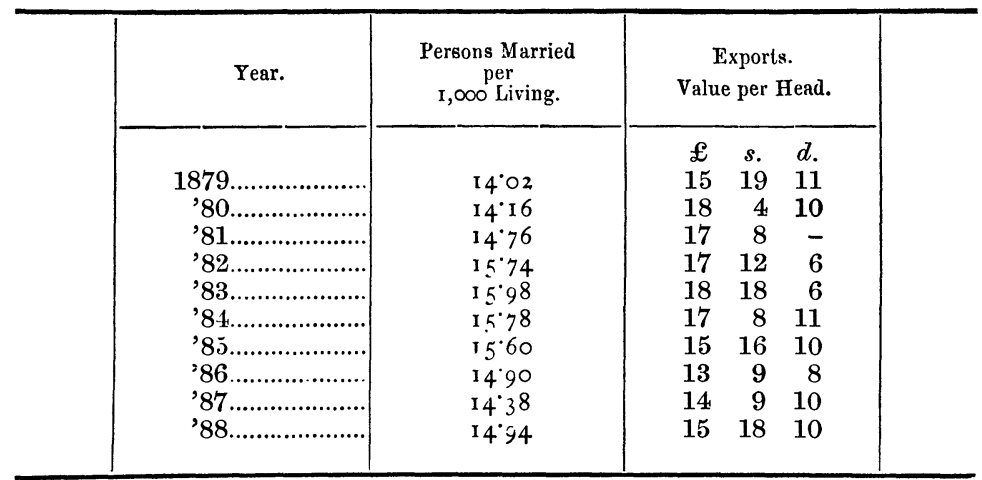

While according to Table A in Dr. Ogle's paper, in known years of prosperity such as 1872 and 1873, a high marriage-rate, 
synchronised with a high export rate in this country, in the same way in the Australasian colonies during 1882 and 1883, the rates both for marriage and export were high; still no proper conclusions could be deduced from those figures. A great many more factors must be brought into play before the problem which Dr. Ogle had tried to solve could be satisfactorily settled. Dr. Ogle had said that when exports increased so also did freights, and the rise in freights caused a corresponding rise in wheat, but that conclusion was manifestly a non sequitur. Of course, if the export of goods and manufactures increased, shipowners took advantage of this to raise the rate of freights, but it did not follow that because vessels earned a higher freight outwards they should also do so homewards. The shipowner looked for profit at the earnings on the voyage all round, and if he got a higher rate outwards he would be prepared to accept a lower rate homewards, so that if the return cargo happened to be wheat, it might be carried at a very low freight, and the article would in consequence show no rise in value. Dr. Ogle sought to explain the great divergence of the marriage curve from the export curve in Diagram A, by comparing the years 1866 with 1888, wherein he found a difference of 3.3 in the marriage-rate coincident with an export value very nearly identical. Why were those particular years selected in the period 1857-88? Because there were other groups of two years within the same period which would answer the same purpose, although exhibiting quite a different result. For instance, in 1867 and 1887 the value of exports per head of population was identical within a few pence, and yet the difference in the marriage-rate was $2 \cdot 3$. Dr. Ogle sought to apply the difference of 3.3 between 1866 and 1888 to the whole period between 1857 and 1888, and on this hypothesis assumed a reduction of 4.65 , whereas the actual reduction was $2 \cdot 3$, exactly the same as that between 1867 and 1887. He seemed to think that the area of country suitable for emigrants was gradually decreasing, but there was a great portion of the earth still requiring to be populated, if men and women could be persuaded to emigrate instead of remaining as limpets on their native rocks. In conclusion, he observed with regard to the middle and upper classes, that a very important factor in the marriage question was the luxury rampant everywhere. A girl was frequently not allowed to marry unless her parents were satisfied that there was a sum provided for her maiutenance at the outset equal to that which the parents themselves had acquired after many years of toil and labour.

Mr. S. Bourne thought that Dr. Ogle was right in regarding the amount of exports as the best test of the prosperity of the country. If therefore the marriage-rate increased with the prosperity of the country, and coincided with the rise of exports, there must be a strict relation between the two, the one causing and the other proving the prosperous condition of the trade of the country. $\mathrm{He}$ agreed with Mr. Paul's opinion in regard to the matter of freights. When the outward freights were high, there was keen competition among shipowners to get something to take back, and 
so the return freights were oftentimes reduced. He thought there was scarcely any correspondence between the freight paid for wheat brought home and the price it fetched in the market when it arrived. The prevailing disinclination to marriage in the upper classes more than in the lower was to be accounted for in a great measure by the luxury in which they were in the habit of living, and he looked upon it as one of the most fatal blots in the condition of the country. He did not think a greater stigma could be cast upon the manhood of England than the proof the paper afforded that men were more ready to marry when they could get wives who could contribute to the purse. With regard to the diminution of facilities for emigration, he thought Dr. Ogle had fallen into a very serious error. The increase of shipping facilitated the transference of the population to other parts i $f$ the world, and the reason it was not more extensively availed of was the absurd idea that people must stick to the barren rock on which they were born rather than go to the fertile fields of other portions of the British $\epsilon$ mpire. He did not agree with Dr. Ogle that a deliberate attempt should be made to diminish the number of marriages, but preferred that homes should be found for the population as it increased in portions of the empire which were greedy to receive them. Nothing was doing more mischief to the country than the restraint of matrimony, and it would be a most serious injury if the Society stood forward as the champion of any such means of restraining the population as were set forth in the paper. They should rather bend their forces towards the utilisation of the means provided in the colonies, and encouraging more careful living at home.

Dr. G. B. Longstaff said he admired the extremely in genious reasoning which ran through the paper, and he was only disposed to differ from the author on the question of freights. It appeared to him that there was a possible relationship between the high price of corn and the increase of the marriage-rate in this way: in times of prosperity amongst the lower orders there was reason to suppose that a very great waste of food took place, and presumably the price of corn would be to that extent kept up by the greater carelessness in using it. As regarded the question of room for new populations in the colonies, he was disposed to agree with Dr. Ogle. Anyone who considered the history of the world must see that a most extraordinary crisis had been passed through during the lifetime of many now present. Malthus thought he saw very clearly the coming of the end. Not very long after his death there was an astonishing opening out by railways in the western territories of the United States, and also in Australia. But there was not another United States nor another Australia; there was not even another Argentine Confederation. In short, although the immediate end of the capacity of those countries was not yet in sight, practically the complete geography of the world was known, and there were no enormous areas of fertile land still unutilised. It was assumed very often by people who were rather loose in speaking or writing on this subject, that the great prairies 
of West America were simply occupied in growing wheat for Europe; but that was very far from being the case. America itself was now consuming a quantity of wheat out of all proportion to what she did thirty or forty years ago, and the colonies were filling up much more rapidly than was generally imagined. He considered that the position of Massachusetts and portions of the State of New York was practically the same as England; they could not produce anything like the quartity of food they required for themselves. It was very difficult to say when the time would come, but in a paper read not long ago before the Society, Mr. Giffen said that in the middle of next century the pressure of population would be so great as to show itself very clearly in prices. His own idea was that we were not very far off the minimum in the price of wheat. When the rise had once begun, it seemed to him it would be continuous.

Sir R. W. RAWSON said that in comparing the rate of marriage with the recorded value of exports, it must be borne in mind that that recorded value was a very imperfect indication of the quantity of exports leaving this country, and of the activity of manufacturing industry giving employment to the people. The increased or decreased consumption of British manufactures within the United Kingdom is an important factor for consideration in this matter. There was no doubt that the price of exports was increasing, and the quantities were increasing, but the increase was not sufficient to account for the acknowledged improvement in the condition of trade, and for this reason it would be a mistake to adopt the recorded value of exports as a safe measure of the improved condition of the population.

Mr. A. E. Bateman said that Dr. Ogle had managed to bring together the questions of trade and population in a very interesting manner. Mr. Paul had found fault with the recorded price of wheat, because it had been taken from home grown wheat only. But the prices of wheat in the English market were for the same quality, whether grown in America or at home, so that he thought the column in the paper might be taken as quite what it ought to be. Up to 1854 the values of imports were based on prices of nearly two hundred years before, and the accounts thus did not show the actual value of what was imported. What was wanted to be known was the value at the present time of our trade. Mr. Bourne still stuck to his original contention about the value of exports being: the great test, as opposed to the view of the late Mr. Newmarch and many others that the value of imports is of more importance. In that he thought they were both right and wrong. It was not only the exports that showed the condition of the people: it was also the iucreased value of raw material, food, and manufactures that were brought to England to be used for the comfort of the people. He did not think Dr. Longstaff was quite right in what he said about more corn being consumed in good times. Instead of more brend, meat and other things were eaten in good times, which in bad times the population could not afford. In good 
times and in bad times the consumption of wheat altered very little in this country. With regard to freights it could not be said that sudden changes in their rates would act simultaneously in the production of wheat in India and Russia, although in the course of years these freights had a great effect.

Rev. IsAaC Doxsey said that some very valuable papers had been read by members of the Society, showing that about 1873 the difference between the import and export curves considerably altered, and that difference has gone on increasing; and with that there has been an increasing fall in the marriage-rate. If Dr. Ogle would give a curve showing the imports as well as the exports, it would, he thought, be seen that that difference nearly synchronised with the fall in the marriage-rate.

Mr. Johy B. MaRTin joined in expressing his thanks to Dr. Ogle for a paper which he had not only made remarkably interesting in itself, but had illustrated graphically in the form of diagrams. The corrected Diagram $\mathrm{C}$ showed remarkable symmetry in its curves; and it might be noticed that both in periods of prosperity and of depression the matrimonial curve always lagged a little behind the time, as was shown in the years 1872-73, and 1878-79. This year 1873 was a year well known to have been one of great disturbance, and it had, in fact, become a terror to statisticians; but the curve of Diagram A, though apparently less symmetrical, was the most interesting of all. He might remark, what had not been indicated by any of the previous speakers, that the matrimonial curve must necessarily vary within certain limits, whose extremes Dr. Ogle would know better than anyone else. In a thousand people there must, of necessity, be a fixed number of couples between whom matrimony was possible; but in the years under review, the steamship, the railway, steam power, and electricity had enormously increased the productive power of each individual, which must practically be illimitable; and therefore in comparing the fluctuations of the marriage curve with the curve of exports, two things were brought together which were not strictly comparable. At that period of the evening he did not wish to enter at length into the economic aspect of the paper, which did not, perhaps, come within the scope of the Society. He would not therefore follow Mr. Stephen Bourne on the ethics of marrying women earning money on their own account; but he must join issue with him directly in his views of the question of population, When the vast amount of misery and disease that burden our great cities, and not our cities only but also the rural districts, is considered, he could not advocate the contention that an increase of the population was an unmixed advantage. $\mathrm{He}$ thought that an enormous responsibility rested on those who added to this mass of human rnisery by the addition to it of additional souls of whom only the more vigorous would emigrate, leaving the infirm and diseased to encumber yet more those who were left behind. In a reduction of the growth of population by the exercise of prudential restraint in marriage, eveu at the cost of 
deferring the average age at which marriage was contracted, he looked for the best hope of the prosperity and salvation of the country.

Major Craigie desired to join in thanking Dr. Ogle for a paper which raised important issues and suggested noteworthy conclusions. He thought they had by no means yet heard the last of the discussion started this evening on this subject. He wished to emphasise only a single point, and one he had touched upon on previous occasions, that there was a danger of too much importance being still attached-in deference to former practice-to the price of wheat. There was a time when that price was much more truly an indication of the general level of price of provisions, and of the well-being and food-commanding power of the masses of this country, than at the present time. If the marriage-rate could be compared with prices of meat and other commodities, now entering as potently into the workmen's annual budget, a record might be obtained which might be of greater value. He would only add that one thing seemed to corroborate Dr. Longstaff's remarks about the possible ultimate restriction of the field for emigration in growing populations of the Western States of America, namely, the "booms" or rushes to unoccupied lands lately observed. These showed that opportunities for acquiring settlements or fresh lands of agricultural value were not quite so plentiful as we once regarded them, or as Mr. Bourne perhaps imagined.

The President thought that in speaking of the difference in the marriage age between the upper and the lower classes, Dr. Ogle had omitted to take into consideration the fact that the professional class did not come into existence until they were 23 or 24 years of age, while miners began to be miners as lads. That of course would account for the high proportion of miners marrying at an earlier age compared with professional men.

Dr. OGLe (in reply) said that Mr. Hendriks asked whether the marriage-rates for the earlier years after 1820 had been corrected for differences in the age-distribution of the population at that time as compared with years later on. They had not, nor was it at all necessary that they should be; for though the age-distribution differed much in different countries, it changed very little from time to time in one and the same country, so that any effect such change would have on the marriage-rate was quite unimportant. At the same time he would admit that those early rates were not very trustworthy, as compared with the rates for the years since civil registration was instituted; they were estimates only, made from the data collected by Mr. Rickman; and his only reason for giving them at all, was to show that they did not support the views as to the inverse relation between marriages and the price of wheat, which had been expressed by Mill, Fawcett, and Farr; from which he inferred that they must have founded their opinions upon some foreign marriage figures. 
He was asked why he had taken exports to compare with marriages, and not imports, or exports and imports together; he had given his reason in the paper; it was because he found as a matter of fact that the movements of the export values corresponded more closely with those of the marriage-rates, than was the case with the other values. Another question put to him was, why in trying to estimate the amount of depression in a given number of years caused by the influence, whatever it was, that had been acting on the marriage-rate, he had taken the years 1888 and 1866 as his two points, and not the years 1887 and 1867 , which would have given a different amount; to this he would say that be had naturally taken the last year in the series, and then gone back till he carne to another year in which the export values were the same as in it; and that, though it was quite true that, had he taken 1887 and 1867, the calculated depression would have been slightly smaller, yet the correction would have been in the same direction, and the two curves in Diagram $\mathrm{C}$ would still have resembled each other much more than they did before the correction was applied, which was all he wished to prove; for of course he did not suppose that the calculation was more than rough, or that the depressing force had really acted with such mathematical regularity as suggested. There at any rate were the two diagrams, and he thought it could not be disputed that the correction applied had made the two curves very similar; and the more similar they were the greater the probability that the correction had been made on a true hypothesis. He came now to another criticism which, if the facts were really as stated by his critics, was, he must allow, fatal to that part of his paper which it attacked. He had long been puzzled by the strange fact that the marriage-rate rose and fell with the price of wheat, and he fancied that he had at last found a plausible explanation of the paradox, namely, that marriages increased when the export trade was active, and that this activity caused a rise in freights, which in its turn sent up the price of wheat; but now he was told that this was a mistake, for that when the export trade was active it was only the freights outwards that rose, and that the freights homewards actually were considerably lowered, because of the number of empty ships wanting to return home. Well, if this were so, and he admitted that it was a subject on which his critics apparently were better informed than himself, his argument broke down, but he should have been glad if his critics had not been contented to destroy his explanation, but had given some explanation of their own. There were the figures, and there could be no doubt that it was the case that when wheat rose in price, so did almost invariably the marriage-rate. How did they explain this strange fact? Their statement made the difficulty greater than ever, for now they had to explain how it came about that wheat actually became dearer when the cost of its conveyance to this country, according to them, went down! Objection had been made to his statement that the faculities for emigration were diminishing, and one speaker had said that they were actually increasing owing to cheap steamers; but he was not speaking of 
the difficulties of transit, but of finding suitable places to go to; and as to this he agreed with what had fallen from Dr. Longstaff. Allow even that there were undiscovered tracts in the world of suitable soil, which could take some spare millions from us, at our present rate of increase this would soon be used up, and all that the discovery would do would be to put off the evil day a little lunger. As things were, he heard surely of foreign countries refusing to admit emigrants so readily as they used to; and after all, what he had said was that if emigration was to be the remedy for our surplus growth, it must be applied on a scale vastly greater than ever yet had been the case, for in no single decennium hitherto had more than one-twentieth part of the surplus growth of England and Wales been got rid of in this way. Mr. Bourne attributed the recent fall in the marriage-rate to the luxury of the upper classes; but the upper classes were a small minority; the bulk of the people were labourers and artisans, and it was their marriages that really made the rate, which was scarcely modified by the habits of the upper class. However, in attributing a large share in the depression in marriages to the increased standard of living, he had included all classes; and if Mr. Bourne called the increased standard of confort in the working classes luxury, all he (Dr. Ogle) could say was that he hoped luxury would go on increasing. There was another remark of Mr. Bourne's, to which he could not assent, and that was, that it was a stigma on the working men to say that they married preferentially women who were earning money; surely this was not peculiar to the working classes, and for his part he did not think it was any stigma on a man to say that he did not marry until he and his wife had enough to live on and support a family; indeed, he thought it an act of praiseworthy prudence in a working man to marry a woman who could add to the family income. As to the remark that restrained matrimony produced social evil, he would not dispute this, but over-population in his judgment produced incomparably greater evils. As to the President's criticisms on the table of mean ages, that miners became miners earlier than professional men became professional: this was true, but precautions had been taken to meet this, as would be found on reference to the official report from which the table had been taken; and he would, as the President suggested, add a note to the paper, when it came to be printed, explaining this.

A vote of thanks to Dr. Ogle terminated the proceedings. 